\title{
Article
}

\section{Framing Transactions in Constitutional Law}

\author{
Daryl J. Levinson ${ }^{\dagger}$
}

\section{CONTENTS}

I. INTRODUCTION .................................................................. 1313

II. Framing Private-Law Transactions....................................1318

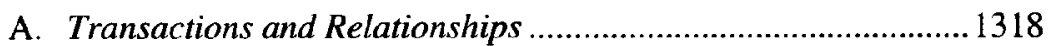

B. Three Dimensions of Aggregation..............................................1326

C. Why and Where Framing Matters .............................................1329

III. FRAMING ConStITUTIONAL TRANSACTIONS ……..........................1332

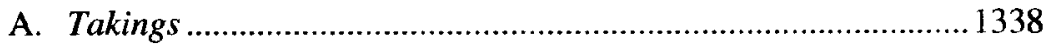

B. Unconstitutional Conditions .....................................................1345

C. Economic Due Process and Rationality Review ........................1350

D. Equal Protection and Race Discrimination .............................1353

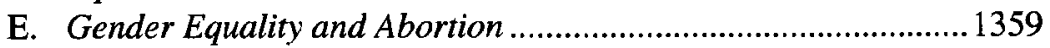

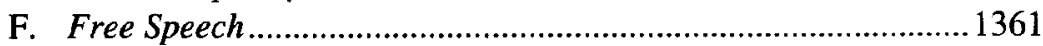

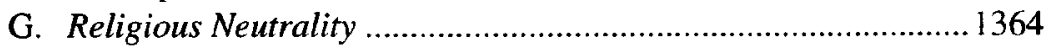

$\dagger$ Professor of Law and Harrison Foundation Research Professor, University of Virginia. Thanks to Barry Cushman, Hanoch Dagan, John Echeverria, Richard Epstein, Barry Friedman, Jack Goldsmith, Don Herzog, John Jeffries, Larry Kramer, Liz Magill, Eric Posner, Richard Posner, Jim Ryan, Peter Schuck, Mike Seidman, David Strauss, Bill Stuntz, Cass Sunstein, and Adrian Vermeule for useful comments on drafts, and to Jackie Sadker, Leah Stewart, and the extraordinary law librarians at the University of Virginia for research assistance. The Article benefited from workshops at Chicago, Harvard, Michigan, N.Y.U., Seton Hall, and Stanford, and especially from the dismantling and reconstruction generously provided by Lewis Kornhauser and Larry Sager at the N.Y.U. Colloquium on Law, Economics, and Politics, and Barbara Fried and Tom Grey at the Stanford Distributive Justice Colloquium. Mike Klarman and Rick Pildes deserve special thanks (but no special blame) for reshaping the project at crucial stages.

1311

Imaged with the Permission of Yale Law Journal 
H. Separation of Powers and Federalism ...................................... 1367

I. Overview: Constitutional Law's Transactional Frame-Up ........1371

IV. TRANSCENDING TRANSACTIONAL HARM ......................................1375

A. Baselines, Frames, and the Emptiness of Transactional Harm 1376

B. Framing Substantive Constitutional Norms. 1383 


\section{INTRODUCTION}

Common-law rules and adjudication are structured around discrete transactions between strangers. The prevailing, classically liberal, model of tort, contract, and property cases features atomistic individuals who interact only at the point of a discontinuous event, sharply limited in space and time. In the case of a tortious collision, for example, the unit of legal analysis, or "transaction," is intuitively defined by the self-contained, harm-inflicting interaction that disrupted the otherwise unrelated lives of the two parties. The focus of adjudication is on the harm to the plaintiff, which can be measured by the marginal deviation from her position or welfare just prior to the collision with the defendant. This model of "transactional harm" operates so ubiquitously and uncontroversially in most common-law cases that we seldom even recognize its significance: Transactional harm is the basic conceptual mold that shapes human interactions into legally cognizable events.

Constitutional cases, like common-law ones, are typically conceptualized as discrete transactions in which government inflicts harm on some individual by making her worse off relative to some baseline position or, under equality rules, relative to some reference individual or group. In the constitutional context, however, the model of transactional harm becomes immediately and irremediably problematic. The problem is that in constitutional law we quickly lose our intuitive grasp on what counts as a transaction for purposes of identifying harm. Unlike the paradigmatic private parties in common-law cases, whose lives intersect only at the point of some discontinuous interaction, government and citizens are not strangers to one another. Quite the contrary, government and citizens, individually and collectively, are engaged in a continuous relationshipone that plays out over a historical time frame and over a scope as broad as the public sphere. When constitutional law borrows the model of transactional harm, it must somehow slice this ceaseless and complex course of dealings into adjudicative transactions for the purpose of evaluating whether government has inflicted a constitutionally cognizable harm. But in the absence of a discrete common-law collision between strangers, constitutional law has no criteria for isolating transactions from the background relationship between government and citizens.

As a result, the "frames" that define constitutional law transactions, when recognized as such, inevitably seem arbitrary and unjustified. And without any way of fixing frames, the entire model of transactional harm falls apart. Most constitutional law regimes ask whether some individual has been harmed by government with respect to some qualitative interest, like speech, property, or equality. Any attempt to answer this question, 
however, will founder on the difficulty that government and citizens, in the course of their ongoing relationship, continuously pass countless harms and benefits back and forth. The question of whether government has harmed some individual citizen (or vice versa) is meaningful only relative to some transactional frame that determines how much of that relationship, which of the multitudinous benefits and harms, should be included within the constitutionally relevant transaction. All the rest, left outside the transactional frame, will dissolve into the background or baseline from which harm is measured.' It all depends on how you slice it. Lacking any natural joints along which to cut, courts and theorists carving out constitutional transactions are left to rely upon inconsistent, manipulable, and normatively opaque intuitions. The results of constitutional cases turn on the location, size, and shape of often-invisible transactional frames that are positioned prior to any deliberation over the meaning or purposes of constitutional rights. This is the basic problem of "framing transactions" in constitutional law. ${ }^{2}$

To make this concrete, suppose that the United States government conscripts a tugboat from a private owner for military use during World War II. ${ }^{3}$ The owner sues under the Fifth Amendment, demanding just compensation for a government taking. No one denies that the owner has suffered the type of economic harm for which takings law demands compensation, but there is some dispute about the magnitude of this harm.

1. The reference to "baselines" in constitutional law will prick up the ears of some readers. The connection between the problem of transactional framing presented in this Article and the baselines critique of constitutional law, exemplified by scholars such as Hale and Sunstein, is discussed infra Section IV.A.

2. The term "framing" is borrowed from Mark Kelman, Interpretive Construction in the Substantive Criminal Law, 33 STAN. L. REV. 591 (1981). Kelman's article describes a number of "interpretive constructs" employed by judges and commentators in shaping substantive criminal law doctrine. One of these is broader or narrower "time-framing" of a criminal defendant's conduct. Id. at 593-94, 600-16. For example, in Kelman's vocabulary, looking at the criminal act of a drug addict in a narrower time frame might make the conduct appear involuntary and blameless, whereas looking at it in a broader time frame that encompasses the addict's initial decision to begin using drugs might make the course of conduct culminating in the criminal act appear voluntary and blameworthy. As will become clear, this Article develops a conception of "framing" that bears only a passing resemblance to Kelman's. (The resemblance is closest in the discussion of expanding frames along a temporal dimension by aggregating harms and benefits over time. See infra Section II.B. But even there, this Article addresses temporal frames as applied to the relationship between two parties rather than, as in Kelman's work, to the life of an individual person.) At a higher level of generality, though, some readers will rightly recognize that this Article seeks to follow Kelman in exposing the substantive issues and judgments buried beneath empty and anodyne doctrinal rhetoric-here, in constitutional law.

"Framing" is also a term of art in the behavioral economics and psychology literature, where it refers to the influence on a decisionmaker's choice of describing options in different ways and, in particular, to the practice of keeping nonfungible "mental accounts" of monetary gains and losses. See Behavioral LAW \& ECONOMICS 6-7 (Cass R. Sunstein ed., 2000); ChOICES, VALUES, AND FRAMES 4-7 (Daniel Kahneman \& Amos Tversky eds., 2000). This Article does not explore the connection between the psychology of individual decisionmaking and the law's approach to framing transactions, although the intriguing connection is well worth noticing.

3. See United States v. Cors, 337 U.S. 325 (1949). 
Against the usual rule that market value is the measure of just compensation, the government argues that the market price of tugboats has been inflated by the government's increased demand during wartime. Certainly the government has inflicted a localized economic harm on the owner by taking his tugboat and depriving him of its market value; but this harm arguably should be offset by a prior benefit afforded the owner by the government, namely, the windfall increase in the market value of his property resulting from the government's war effort. Should the windfall benefit of the war be entirely disregarded, or should it be included in the same transactional frame as the tugboat conscription?

In the actual tugboat takings case, the Supreme Court did indeed allow the government to offset the price effects of its own increased demand for boats during wartime. ${ }^{4}$ After all, the Court reasoned, the inflated market price of the tugboat represents a component of "value which the government itself created and hence in fairness should not be required to pay." 5 But what about other benefits that the government itself created? The value of the tugboat may have been enhanced by a prewar harbor dredging project by the federal corps of engineers that expanded the local harbor, not to mention the rules of property and contract, and their publicly financed enforcement mechanisms, without which the tugboat would have no market value at all. Certainly the government contributed to the owner's general wealth and welfare through innumerable benefits at slightly greater distance, in time or subject matter, from the tugboat-ranging from the Coast Guard and lighthouses to public schools and mortgage subsidies. ${ }^{6}$ As the ledger of costs and benefits thus expands, the net economic harm-or, perhaps, benefit-to the owner quickly becomes indeterminate.

Needless to say, the Court in the tugboat takings case did not even consider expanding the frame far enough to allow the government to offset, or claim restitution for, these "unrelated" benefits. As a descriptive matter, the Court's limited willingness to expand the transactional frame is not entirely unpredictable; it appeals to vague intuitions about the "germaneness" of benefits and costs or the existence of a chronological or subject-matter "nexus" between them. Normatively, however, the placement of transactional frames is always deeply puzzling. The takings right is conventionally understood to protect individuals from bearing severely disproportionate economic burdens that should be spread over taxpayers generally. If the focus of takings analysis is on concentrated

4. The Court in Cors decided, by a 5-4 vote, that the right result was to reduce compensation to the pre-World War II market value of the tugboat. Id. at 333-35.

5. Id. at 334 .

6. And once we stant down this road, it would seem unfair not to allow the owner to count some benefits of his own, starting with a lifetime of tax payments.

7. E.g., Armstrong v. United States, 364 U.S. 40, 49 (1960) (stating that government must not "forc $[e]$ some people alone to bear public burdens which, in all faimess and justice, should be 
economic burdens, then any offsetting economic benefits that would reduce or eliminate these burdens would seem equally relevant. As long as the takings right is understood to be about economic burdens on individual property owners, it is difficult to imagine normatively meaningful limitations on the kinds of offsetting benefits that government might invoke to argue that it has implicitly compensated its taking. Limiting the transactional frame to include some offsetting benefits but not others seems perfectly arbitrary.

Unfortunately, the problem of framing transactions is in no way unique to takings jurisprudence. In virtually every area of constitutional law, rights are conventionally understood to protect individuals against transactional harm to some qualitative interest. For example, free speech jurisprudence is widely understood to protect an individual's speech against government suppression; equal protection jurisprudence is widely understood to protect members of racial or gender groups against selective disadvantages imposed by government; and Religion Clause jurisprudence is widely understood to prevent government from advantaging religious groups relative to nonreligious groups or the other way around. In each of these settings, and many others, however, government will usually be able to point to numerous respects in which it has benefited the very same constitutionally significant interest that is now, in some particular respect, burdened. If our complete understanding of the constitutional right at stake is that it protects against government-inflicted harm to that interest, we will have no criteria internal to constitutional analysis for deciding why any allegation of constitutional harm should not be offset by some handful of government-conferred benefits. Transactional frames will determine the outcome of cases, but decisions about how to frame will seem strategic or arbitrary-insofar as they are even recognized as decisions at all.

As this Article attempts to demonstrate, the problem of framing constitutional transactions is insoluble in its own terms. Fortunately, though, we need not accept these terms. Framing puzzles inevitably result from the misguided attempt to superimpose a common-law model of discrete, individualized harm on the continuous, benefit-laden relationship between government and citizens. Once we recognize that constitutional rights cannot be modeled in the same way as common-law ones, however, we might shift the focus of constitutional analysis from transactional harm suffered by individuals to more systemic types of government failure and

borne by the public as a whole"); United States v. Sponenbarger, 308 U.S. 256, 266 (1939) (explaining that the compensation requirement for takings "is grounded upon a conception of the injustice in favoring the public as against an individual property owner"); LAURENCE H. TRIBE, AMERICAN CONSTITUTIONAL LAW 605 (2d ed. 1988) (stating that the prohibition on uncompensated takings places "a limit on government's power to isolate particular individuals for sacrifice to the general good," based on the principle that "society simply should not exploit individuals in order to achieve its goals"). 
how these failures might be prevented through constitutional adjudication. Rather than reflexively understanding every constitutional right as preventing a simplistic type of harm to some individual, courts and theorists might begin by developing thicker accounts of constitutional norms, ${ }^{8}$ reflecting substantive moral and policy judgments about what, exactly, constitutional norms are supposed to accomplish by way of improving the behavior of government and how they might be designed and applied to realize these purposes. ${ }^{9}$ This approach would change both the stakes and the strategies of framing. Frames would no longer dispositively determine constitutional liability by creating or negating individualized harm, but instead would simply direct judicial attention to the types and patterns of government behavior that are significant for purposes of implementing particular constitutional norms. Moreover, the choice of frames would no longer seem mysteriously independent of courts' and theorists' best understandings of constitutional provisions, but instead would follow instrumentally from those understandings.

This Article's primary topic is constitutional law, but it arrives there by a circuitous route. Part II discusses the relatively unproblematic structure of transactions in private-law cases, where government is not a party to litigation. " "Relatively" should be emphasized here, for private-law regimes governing repeat-play relationships and those potentially concerned with the treatment of social groups (as opposed to individuals) quickly run into the types of framing questions that haunt public-law regimes. " This Part also lays out a conceptual taxonomy of the dimensions along which transactional frames may be expanded or contracted by aggregating harms and benefits: over time, over subject-matter scope, and over groups of individuals. Part III turns at last to constitutional law and presents the main argument of the Article. It attempts to demonstrate that any conception of constitutional rights that turns on transactional harm or a departure from government "neutrality" will encounter insuperable difficulties in deciding how to frame transactions. As Part III exhaustively

8. Throughout the Article, the term "norm" is used as an approximate synonym for "right" in order to shade the meaning away from an individual entitlement not to be harmed.

9. As discussed infra Section IV.B, to some extent they already have.

10. This Article's usage of the terms "private law" and "public law" may be idiosyncratic. Private-law cases are simply those in which the plaintiff and defendant are both private parties, whereas public-law cases are those in which a government actor is on at least one side of the litigation, if not both. This distinction is not meant to carry any additional descriptive or normative weight. In particular, it is in no way meant to endorse any sort of deep distinction between legal regimes that are the product of government and those that are not. Such a distinction would be foolish in light of the baselines critique discussed infra Section IV.A.

11. Although the Article does not discuss nonconstitutional public-law regimes in which analogous framing problems arise, it should be obvious that much of what is said about constitutional law applies here with little modification to any legal regime regulating the government-citizen relationship, such as administrative law or the law of tort or contract as applied in claims against state actors. 
illustrates, the problem of transactional framing is pervasive in constitutional law, undermining conventional approaches to the jurisprudences of takings, unconstitutional conditions, rationality review, race and gender equal protection, free speech, religious neutrality, separation of powers, and federalism. This does not mean that constitutional law is inevitably arbitrary or incoherent, however. Part IV picks up the pieces of Part III and suggests that constitutional law can be sensibly reconstructed by elaborating constitutional rights on models other than the common-law one of transactional harm. Once we are clear about the substantive commitments that constitutional provisions are meant to serve, their instrumental roles in furthering these normative goals, and the institutional limitations of courts and other political institutions in implementing them, then the problem of framing transactions can be resolved at retail, for particular constitutional norms.

\section{Framing PRIVATE-LAW TRANSACTIONS}

\section{A. Transactions and Relationships}

Common-law rules and adjudication are oriented around discrete, harmcausing (or, occasionally, benefit-conferring ${ }^{12}$ ) transactions between private parties. This is the case whether the goals and mechanisms of common-law regimes are understood in terms of efficiency and incentives or morality and corrective justice. If $A$ negligently runs over $B$, or breaches a contract with her, he will be forced to compensate $B$ for that harm ${ }^{13}$-whether the rationale is understood as forcing $A$ to internalize the cost of his negligence in order to create incentives to invest in efficient precautions, or as enforcing a moral duty to rectify wrongdoing. ${ }^{14}$ In both the economic and corrective justice conceptions, the relevant sufferers of harm are usually understood to be individual actors (even if the "individual" is in fact a firm). Liability is triggered by a discrete alteration of the status quo between the plaintiff and defendant, localized in time and space: This

12. Restitution, or unjust enrichment, doctrines in various areas of law allow plaintiffs who have conferred nonconsensual benefits on defendants to sue for compensation. The transactional structure of these cases is parallel.

13. Of course, not all instances of what intuitively might be seen as harm-infliction trigger legal liability. Most torts, for example, require negligence on the part of the defendant; nonnegligent harms usually do not trigger liability. The understanding of "harm" employed here and elsewhere in the Article is purely positive, limited to legally cognizable harms. For present purposes, we may remain agnostic as to how legal regimes go about deciding what counts as an actionable harm.

14. See Richard A. Posner, The Concept of Corrective Justice in Recent Theories of Tort Law, 10 J. LEGAL STUD. 187 (1981) (demonstrating that corrective justice accounts of tort and contract are compatible with economic accounts at the level of generality discussed in this paragraph). 
defines the relevant transaction. ${ }^{15}$ Once a bounded transaction has been established, assessments of harm follow straightforwardly. Harm is measured against the baseline of the status quo ante welfare level of the plaintiff, before the defendant ran into her, with the magnitude of the harm measured by the marginal change in welfare resulting from the defendant's conduct. Remedially, the defendant is usually obligated to compensate the plaintiff for harm caused, restoring her pretransactional baseline level of welfare. ${ }^{16}$ This model of "transactional harm" is widely accepted in common-law and other private-law settings.

Notice that the hub of the model is a well-defined transaction. The boundaries of the transaction determine the parties, the status quo distributive baseline from which harm is measured, and the marginal change in welfare that determines the extent of harm. The size and shape of the transaction dictate how much of whose lives will be transformed into a legal event. Fortunately, defining the relevant transaction presents few difficulties in the typical common-law case. The paradigmatic common-law case involves a discrete, bilateral interaction between two strangers. It is relatively straightforward in such a case simply to draw a circle around the discontinuous, harm-causing collision or contract breach. This circle-or "frame"-defines the legally significant transaction between the parties, and once this has been accomplished, the rest of the model works mechanically. The parties are identified; the distributive baseline is drawn just prior to the collision or contract breach; and the harm is the marginal reduction in the welfare of one of the parties resulting (more or less directly, depending on proximate cause judgments) from that event. Every common-law case must be framed as a transaction in this sense for the model to work; but because the appropriate frame is ordinarily so uncontroversial, the framing step usually remains unconscious and invisible.

Suppose, however, that the victim of $A$ 's negligent driving or contract breach, $B$, is not a stranger but $A$ 's longtime neighbor, and that this particular interaction is one of a long series of harm-causing and benefitconferring exchanges between them. Now it becomes possible, at least in theory, for the law to frame a transaction between $A$ and $B$ in more than one way. Instead of drawing a tight circle around the accident or breach and holding $A$ accountable for the resulting harm to his neighbor on the spot, the legal regime might frame the transaction more broadly, as a larger slice of

15. David Johnston, Beyond Compensatory Justice?, in NOMOS XXXIII: COMPENSATORY JustiCE 330, 337 (John W. Chapman ed., 1991); Cass R. Sunstein, The Limits of Compensatory Justice, in NOMOS XXXIII: COMPENSATORY JUSTICE, supra, at 281, 281-82.

16. The expectation measure of contract damages is a slight exception to this statement, as it substitutes a baseline of post-performance welfare. And of course damages are sometimes set higher or lower than the perfectly compensatory level for instrumental or administrative reasons. 
their ongoing relationship. At the extreme, the legal regime could keep a ledger of all legally cognizable harms and benefits over the entire course of the $A-B$ relationship, perhaps only requiring (or allowing) a reckoning when the relationship terminates-at which point the bottom-line debtor might be required to compensate the bottom-line creditor. There are many conceivable reasons why legal regimes might want to "aggregate" harms and benefits in this way using broader transactional frames rather than insist upon narrowly framed, interaction-by-interaction legal intervention. Most obviously, the harm suffered by $B$ as a result of this particular tort or contract breach might be offset, or more than offset, by past or future benefits conferred upon her by $A$, or reciprocal harm inflicted upon $A$ by $B$. If the point of a legal regime is to prevent "harm," the question remains whether harm should be understood more locally or more globally. If the latter, then a broader transactional frame could at least have the advantage of economizing on administrative costs. ${ }^{17}$ In some contexts, moreover, legal intervention in the course of a relationship, rather than just at the close, risks interfering with the development and operation of relational norms that would otherwise obviate much of the need for legal regulation. ${ }^{18}$ Whatever the advantages and disadvantages of a broader or narrower transactional frame in any particular context, the important point is that, when parties are engaged in a repeat-play relationship that offers many harms and benefits for potential aggregation, the appropriate boundaries of the transaction are no longer obvious.

Again, in many common-law contexts, the relevant parties are strangers to one another, their collisions or contracts are isolated or at best intermittent events, and, consequently, framing choices simply do not arise. ${ }^{19}$ But even in relational contexts where a broader transactional frame is possible, common-law regimes ordinarily resist expanding beyond localized interactions. To the extent that aggregation occurs at all, it is usually limited to harms and benefits stemming from the very same interaction (intuitively defined). So, for example, a surgeon who operates on a patient without consent and causes pain and suffering may be able to offset the value of future pain and suffering averted by the operation, ${ }^{20}$ and a surgeon who negligently performs a sterilization procedure may be able to

17. Economies would be available up to the point at which the additional administrative or litigation costs of maintaining a long-term ledger outweighed the savings from having fewer trials or settlements.

18. Robert C. Ellickson, ORDER Without LAW 249-58 (1991); David Chamy, Nonlegal Sanctions in Commercial Relationships, 104 HARV. L. REV. 373, 426-30 (1990); Eric A. Posner, The Regulation of Groups: The Influence of Legal and Nonlegal Sanctions on Collective Action, 63 U. CHI. L. REV. 133, 155-60 (1996).

19. Even in these settings, there are opportunities to frame more broadly by aggregating over groups. See infra notes 30-35 and accompanying text.

20. RESTATEMENT (SECOND) OF TORTS $\S 920 \mathrm{cmt}$. a (1977). 
offset the benefits of parenthood against the costs of child rearing. ${ }^{21}$ Each operation is regarded as its own transaction. Harms and benefits within a transaction can be aggregated and offset, but aggregation across separate transactions (or combining separate interactions into a larger transaction) is forbidden. Compare the altruistic surgeon who volunteers to perform lifeextending heart-bypass surgery on an uninsured patient too poor to afford the operation and then, some years later, negligently treats that very same patient with a heart-attack-inducing medication. Most judges and lawyers would scoff at the prospect of combining the two operations into a single transaction and allowing the surgeon to offset the earlier benefit against the later malpractice harm.

In at least a few repeat-play contexts, though, common-law and statutory regimes go somewhat further in aggregating multiple interactions into broader transactions. Legal regimes governing marriages, for example, tend to ignore relatively minor household disputes or instances of opportunistic behavior by spouses during the marriage. ${ }^{22}$ In effect, the law relies on social and relational norms to ensure that rough reciprocity of benefits and burdens obtains over the course of the relationship, only intervening in instances of extremely high-stakes opportunism and at the point of dissolution. ${ }^{23}$ Similarly, private-law regimes take a relatively laissez-faire attitude toward at least some types of disputes between parties to relational contracts, ${ }^{24}$ workers and employers, ${ }^{25}$ workers and unions, ${ }^{26}$ members of informal trade groups, ${ }^{27}$ residential associations, ${ }^{28}$ and components of corporations. ${ }^{29}$ All of these areas have in common parties who are engaged in some kind of ongoing relationship. Taking the parties' ongoing consensual participation in the relationship as a signal that harms will be roughly offset by benefits over time, the governing legal regimes may rationalize noninvolvement even where these same harms and benefits, considered in isolation, would be legally cognizable. We might think of

21. See 2 DAN B. DOBBS, LAW OF REMEDIES 417-20 (2d ed. 1993).

22. The traditional common-law view was that spouses could not sue one another for torts or breaches of contract. I HOMER H. ClARK, JR., THE LAW OF DOMESTIC RELATIONS IN THE UNITED STATES 631 (2d ed. 1987). These rules have become softer over time, but the general point remains valid.

23. Elizabeth S. Scott \& Roben E. Scott, Marriage as Relational Contract, 84 VA. L. REV. 1225,1230 (1998).

24. See Lisa Bernstcin, Opting Out of the Legal System: Extralegal Contractual Relations in the Diamond Industry, 21 J. Legal STUD. 115 (1992); Charles J. Goetz \& Robert E. Scott, Principles of Relational Contracts, 67 VA. L. REV. 1089 (1981); Robert E. Scott, Conflict and Cooperation in Long-Term Contracts, 75 CAL. L. REV. 2005 (1987).

25. Charny, supra note 18 , at 395-97.

26. Posner, supra note 18 , at 181.

27. Id. at 173-75.

28. See Clayton P. Gillette, Courts, Covenants, and Communities, 61 U. CHI. L. REV. 1375 (1994).

29. Oliver E. Williamson, Economic Institutions: Spontaneous and Intentional Governance, 7 J.L. ECON. \& ORG. 159, 164-65 (1991) (Special Issue). 
these relational legal regimes as defining the relevant transaction as a larger slice of the relationship, or perhaps even as the relationship as a whole.

Up to now, the assumption has been that no matter how broadly a transaction is framed in other respects, net harm is ultimately calculated at the level of an individual victim. This is how the common law almost invariably operates. There are, however, a few exceptional common-law rules that might be understood as evaluating harm at the level of some group. For example, suppose a cement company that is the economic heart of a small industrial town releases harmful dust that injures several nearby residents. When the residents sue for damages, the factory may successfully argue that, although it would otherwise be subject to strict liability as an ultrahazardous activity or nuisance, in this case it should not be liable for nonnegligent harm because its value to the community compensates for its dangerous attributes. ${ }^{30}$ The argument, in effect, is that the nonnegligent harm inflicted by the factory on members of the community is offset by the positive externalities conferred upon them. ${ }^{31}$ For this argument to succeed, the transactional frame must be enlarged to take account of past and future economic benefits to the town-not just benefits directly related to pollution or the environment, and not just benefits in the same time slice as the pollution harms. But the argument also requires enlargement along a further dimension, to take account of the benefits and harms experienced not just by a single individual plaintiff, but by the community as a whole. Inevitably, some individuals in the class of plaintiffs will not personally enjoy sufficient economic benefits from the operation of the factory to justify a claim of implicit compensation for the pollution harm they have suffered. The factory essentially asks the court to aggregate the entire town into a single entity, so that benefits to some residents can offset harms to others. ${ }^{32}$ On this theory, accounting of net harm takes place at the level of the group, not at the level of any particular individual within the group. Harm to one group member can be offset by benefit to a different group member.

30. See RESTATEMENT (SECOND) OF TORTS $\$ 520(\mathrm{f}) \mathrm{cmt}$. k (1977) (excepting those dangers that substantially enhance the net utility of the affected community by providing public benefits like increased employment and tax revenues from the general rule of strict liability for "abnormal" dangers).

For an analogous case involving a local government defendant, see Albig v. Municipal Authority of Westmoreland County, $502 \mathrm{~A} .2 \mathrm{~d} 658$ (Pa. Super. Ct. 1985). It is interesting to observe how troubled the dissenting judge in Albig was by the group aggregation aspect of the majority's decision. He argued that the Restatement section 520(f) exception to strict liability should apply only "when the individuals imperiled by the activity are also the individuals benefited by the activity." Id. at 668 (McEwen, J., dissenting).

31. This depends on the baseline assumption that nonnegligent harm is legally cognizable. As throughout this Article, what counts as a legally cognizable harm or benefit should be taken as primitive.

32. Note that the law already treats the factory in this way, as a unified individual entity, rather than disaggregating it into stockholders, employees, and the like. 
Another example of this kind of "group aggregation" in tort emerges from cases in which courts deny recovery to plaintiffs who have suffered pecuniary harm but no damage to person or property, invoking the "rule" that economic loss standing alone is not recoverable in tort. ${ }^{33}$ Suppose a barge negligently crashes into a bridge, destroying the only link between an island and the mainland. ${ }^{34}$ Businesses on the island are cut off from their customers and supplies. These businesses sue the barge owner for their lost profits, which would seem to constitute a very real type of harm resulting from the defendant's negligence. But the court refuses any recovery for these pure pecuniary losses. One justification for this seemingly odd result is that the economic losses suffered by the island businesses are roughly offset by the economic gains to businesses on the mainland, which captured many of the customers who could no longer reach the island. ${ }^{39}$ For this justification to work, however, the benefits to some individuals must be offset against harms to others. Island and mainland businesses must be aggregated into a single group for purposes of calculating net harm.

These examples notwithstanding, group aggregation is rare in commonlaw regimes, which ordinarily insist on individual-level accounting. ${ }^{36}$ Group aggregation, or at least its possibility, is much more significant in certain statute-governed private-law contexts involving groups with some extralegal status or salience. For example, Title VII of the Civil Rights Act forbids an employer from discriminating against any individual with respect to the terms or conditions of employment on account of race or sex. ${ }^{37}$ This seems simple enough in the abstract. But consider a case in which for every female employee who is burdened in some way because of her gender, there is a different female employee who is afforded a special benefit of equal magnitude just because of her gender. Should we view this case as a series of transactions, each of which amounts to discrimination because of sex and therefore violates Title VII, or should we instead view this case as a single transaction in which female employees as a group are treated neutrally? In Los Angeles Department of Water \& Power v. Manhart ${ }^{38}$ for example, an employer required female employees to pay more than male employees for pension benefits because of their longer life expectancy. Focusing on the plight of the individual female who would not live longer

33. See Restatement (SeCOND) OF TORTS $\S 766 \mathrm{C}$ (1977); W. PAge KeEton eT aL., PROSSER \& KEETON ON THE LAW OF TORTS $\$ 130$ (5th ed. 1984).

34. These facts are based on Rickards v. Sun Oil Co., 41 A.2d 267 (N.J. 1945).

35. See Richard A. POSNER, ECONOMIC ANAlysis OF LAW 201 (5th ed. 1998); W. Bishop, Economic Loss in Tort, 2 OXFORD J. LEGAL STUD. 1 (1982).

36. Another possible tort-law example of aggregation over groups with no independent social significance is probabilistic recovery by a plaintiff class. See David Rosenberg, The Causal Connection in Mass Exposure Cases: A "Public Law" Vision of the Tort System, 97 HARV. L. REV. 849 (1984).

37. 42 U.S.C. $\$ 2000 \mathrm{e}-2$ (a) (1994).

38. 435 U.S. 702 (1978). 
than the average man and, as a result, would pay "too much" for the pension benefits she would receive, the plaintiffs claimed that this amounted to sex discrimination. But of course, for every short-lived female employee there would be a long-lived one who would pay "too little" for pension benefits, so that female employees as a class were not treated worse than male employees as a class. The case thus turned on the Court's willingness to aggregate harms and benefits to female employees as a group, allowing benefits to some individual employees to offset, or implicitly compensate for, harms to others. ${ }^{39}$

Similarly, courts in Title VII cases involving race discrimination have been confronted with employers who attempt to defend the disadvantageous treatment of some minority employees by pointing to an offsetting affirmative action program that benefits others. ${ }^{40}$ Should the racially assigned burdens to some employees be aggregated together with, and offset by, the racially assigned benefits to others? On the one hand, a given employee who is denied a promotion on account of his race will take little solace in the fact that another minority employee somewhere else in his company has been "compensated" with a promotion. On the other hand, one might question how there can be race discrimination in employment if a new employee would have no basis for predicting that he would be better or worse off if his race were different. ${ }^{41}$

Group aggregation in cases where the legal norm is based on equal treatment can take place both within a particular group (e.g., female employees) and between comparison groups (e.g., between female and male employees). If the male supervisor of a female employee threatens to block her promotion unless she sleeps with him, or if he creates a hostile environment for her, then the employer may be liable for quid pro quo or

39. The Manhart Court, in a 5-2-1 decision, ultimately agreed with the plaintiffs, finding that the "basic policy of the statute requires that we focus on fairness to individuals rather than faimess to classes." Id. at 709.

40. See Connecticut v. Teal, 457 U.S. 440 (1982) (5-4 decision). In Teal, an employer attempted to defend a promotion test with a racially disparate impact on the basis of an offsetting affirmative action program. The test and the program together resulted in a higher promotion rate for black candidates than for white ones. The Court rejected this "bottom-line" defense and allowed plaintiffs to challenge the discriminatory impact of the test in isolation. "It is clear," the majority explained, "that Congress never intended to give an employer license to discriminate against some employees on the basis of race or sex merely because he favorably treats other members of the employees' group." Id. at 455. The dissent found it equally clear that "[ $\mathrm{t}]$ here can be no violation of Title VII on the basis of disparate impact in the absence of disparate impact on a group." Id. at 459 (Powell, J., dissenting); see also Furnco Constr. Corp. v. Waters, 438 U.S. 567 (1978) (deciding that statistics demonstrating racial balance in the overall workforce are relevant to a "disparate treatment" claim under McDonnell Douglas Corp. v. Green, 411 U.S. 792 (1973)).

41. The question of group aggregation can always be rephrased in terms of ex ante versus ex post positions. In the gender and race discrimination cases just discussed, we might ask whether the appropriate vista is ex ante, where a risk-neutral employee might be indifferent as to whether the employer maintained the challenged practice, or ex post, where an employee who comes out on the losing end of the practice will have a strong individual claim of discrimination. 
hostile environment sexual harassment under Title VII. ${ }^{42}$ Suppose, though, that in response to a claim of quid pro quo sexual harassment brought by a female employee, the employer comes forward with evidence proving that the same supervisor made a similar threat to a male employee. This is the notorious case of the "equal opportunity sexual harasser." Courts and commentators have puzzled over whether the equal opportunity sexual harasser violates Title VII, but the majority view seems to be that there is no sex discrimination because the supervisor's bad treatment of both a female and a male employee suggests that he did not act because of sex. ${ }^{43}$ Now, consider this variation on equal opportunity sexual harassment: Male partners in another law firm routinely harass the female associates by sexually propositioning them, making lewd jokes, and the like. To make matters worse (or perhaps, from a legal perspective, better), because these partners regard the male associates as sexual rivals, they subject them to highly adverse working conditions, deny them promotions, and only assign them to the most tedious and unrewarding projects. Surely every court would find multiple instances of sex discrimination in this case. Even if it were theoretically possible to compare the special harms experienced by female employees and the special harms experienced by male employees on a single metric, and even if the comparison revealed a perfect offset, so that female and male associates received precisely "equal" (albeit qualitatively quite different) treatment, courts would no doubt see two sets of Title VII violations-sexual harassment of women and sex discrimination against men-instead of offsetting them and seeing none.

This result is easy to predict but difficult to explain. Whether a situation like this amounts to a statutory violation depends on whether "discrimination because of sex" is determined at the level of the individual employee, in which case a female employee can establish liability by showing that this particular supervisor harassed her because of sex, or at the level of working conditions for men and women as groups, in which case the employer can defeat liability by showing that female and male employees are treated equally on balance. In other words, the result turns on the extent to which the law will aggregate over groups. Should sexual harassment law worry about particular instances of differential treatment on the basis of sex; or should it aggregate the harms suffered by all female employees, separately aggregate the harms suffered by all male employees, and compare? In order to answer this question, we would have to know more about what sexual harassment law is supposed to accomplish. Should the legal regime push for gender equality at the level of the workplace as a

42. E.g., Meritor Sav, Bank v. Vinson, 477 U.S. 57 (1986) (recognizing claims for sexual harassment under Title VII and distinguishing hostile environment and quid pro quo harassment).

43. Katherine M. Franke, What's Wrong with Sexual Harassment?, 49 STAN. L. REV. 691, $719-20$ \& n.140 (1997) (summarizing the majority view). 
whole, or should it protect individual employees against adverse treatment on account of their gender? There are good reasons for endorsing either of these goals, but they are not the same. Until we are clear on when and why sexual harassment is bad, indeterminacies of aggregation and framing will persist, and fundamental normative questions will be answered only implicitly, without candid debate or justification.

\section{B. Three Dimensions of Aggregation}

From this cursory discussion of legal regimes governing the interactions of private parties, a taxonomy of transactional frames emerges. Let us designate as the atom of a legal transaction some discrete, individual-level interaction between two private parties involving the infliction of some legally cognizable harm or the conferral of some legally cognizable benefit. Ordinarily, private-law rules treat a single such atom as an independent transaction. Occasionally, however, legal regimes aggregate a number of atoms into a molecular transaction. As we have seen, this sort of aggregation may take place along several different dimensions.

First, as between two or more individuals or firms, harms and benefits may be aggregated over time. For example, an employer who disadvantages a female employee on the basis of gender on Monday, and then equally advantages her on Friday, may be liable for sex discrimination or not depending on whether the temporal dimension of the transactional frame is the duration of a day or a week. Likewise, the physician who confers heroic benefits on a patient in January and commits malpractice on the same patient in June will be eager to bring these two events into at least a semiannual transactional frame. In real life, of course, neither the employer nor the physician will likely prevail. But the spouse who engages in an extramarital affair may successfully avoid liability, in a sense, by implicitly invoking a longer time frame in which various offsetting benefits might compensate the other spouse who chooses to stay married. And even the Monday-Friday employer, under the right circumstances, may be able to bring sex-based advantages and disadvantages into the same frame of reference by justifying the advantages as an affirmative action program designed to remedy past discrimination.

Second, as between two or more individuals or firms, harms and benefits may be aggregated in scope. For example, a factory that would otherwise be liable for pollution damages may argue-in the political or public relations context, if not in court-that the victims of pollution are also economic beneficiaries of its productive activity (as employees, taxpayers, or consumers of public goods) and therefore have not experienced any net harm. In making this argument, the factory is essentially asking that the transactional frame be broadened to include not 
just its harm-causing pollution but also its broader operations and economic effects. The relevant dimension of transactional breadth here is the scope of the factory's dealings with its neighbors (within any given time slice). Needless to say, as a matter of actual law, the factory almost certainly will not succeed in court. Private-law regimes tend to take an extremely narrow view of the scope of transactions. According to the Restatement of Torts, for example, if a defamation plaintiff sues for lost income, the defendant may show that the publicity resulting from her defamatory remarks enabled the plaintiff to earn large lecture fees; but if the plaintiff sues for emotional distress and loss of reputation, then the lecture fees are irrelevant because they do not benefit the precise "interest" of the plaintiff that was harmed. ${ }^{44}$ In the latter case, the conceivable transaction of defamation followed by public notoriety and lecture opportunities must be split into two separate, smaller transactions: one encompassing the defamation and causally linked emotional distress and the other encompassing the defamation and causally linked lecture fees. ${ }^{45}$ This type of restrictive "germaneness" requirement would clearly rule out most attempts to aggregate over scope-certainly the polluting factory would have a hard time offsetting economic benefits against pollution harms. In this regard, it is worth noticing that the very definition of quid pro quo sexual harassment forbids the aggregation over scope of even very closely related harms and benefits. If a female secretary accepts an otherwise out-of-reach promotion from her male boss in exchange for sleeping with him, the boss will not be able to avoid liability for sexual harassment by offsetting the benefit of the promotion against the harm of coerced sex within the same transactional frame. ${ }^{46}$

Third, even where harms and benefits do not offset at the level of a given individual, they can be made to offset by aggregating them at the level of some group. The driver of a black car negligently runs a light and crashes into a white car passing through the intersection. The driver of the white car sues the driver of the black car for tort damages. If the driver of the black car were clever and knew nothing of tort law, he might try to argue that, although it is unlikely that the plaintiff herself will do similar damage to his own car in the future, drivers of white cars as a group will likely inflict as much negligent damage on owners of black cars as the other way around. Consequently, the argument might go, tort law should allow these harms to offset, in effect defining the relevant transaction as the single, enormous "collision" between the groups of white and black cars rather than this particular two-car accident. This argument sounds crazy, but

44. Restatement (SeCOND) OF TORTS \$ 920 (1977).

45. The second of these smaller transactions might be translated into a claim for restitution, though probably a losing one.

46. This is another way of seeing the familiar paradox of blackmail. It is analytically identical to the unconstitutional conditions problem, discussed infra Section III.B. 
only because groups defined by car color (as opposed to, for instance, skin color) are not sufficiently salient or solidary. ${ }^{47}$ In the context of employment discrimination, where we are more accustomed to thinking about harms to sociologically identifiable groups, the argument starts to seem plausible. An employer might attempt to defeat a Title VII discrimination claim by arguing that the total benefits to minority employees in the workplace are equivalent to the total harms, so that minority employees, collectively, have not been disadvantaged relative to some status quo baseline, or relative to the harm suffered by white employees as a group. Conceptually similar disparate impact arguments are widely accepted in Title VII and many other antidiscrimination regimes.

To summarize the conceptual apparatus of transactional framing, if $A$ and $B$ are set up on a blind dinner date and both resolve by dessert never to see the other again, then perhaps they will maintain equality by splitting the tab. If, on the other hand, $A$ and $B$ begin dating and dining regularly, then they might decide to maintain equality by taking turns paying instead of settling up after each date. The ongoing relationship over time enables $A$ and $B$ to aggregate and offset their debits and credits. Now suppose the $A-B$ relationship also broadens in scope. Not only does the couple go out to

47. Actually, a quite similar argument is taken seriously in the tort literature. In a famous article, Professor Fletcher attempts to explain the mixture of strict liability and negligence rules in tort law by the principle that victims are permitted to recover for harms resulting from nonreciprocal risks-that is, risks that probabilistically impose asymmetrical costs and benefits. See George P. Fletcher, Fairness and Utility in Tort Theory, 85 HARV. L. REv. 537 (1972). Fletcher's basic idea is that in some spheres of activity, like driving, a given individual is equally likely to be an injurer or a victim. Where this is true, rather than holding injurers accountable to victims on an interaction-by-interaction basis, it may make more sense to do away with tort liability on the theory that actual victims are implicitly compensated by permission to impose their own risks on others. (For an economic analysis of tort rules based on the similar idea of "bilateral risks," see Jennifer H. Arlen, Liability for Physical Injury when Injurers as Well as Victims Suffer Losses, 8 J.L. ECON, \& ORG. 411 (1992); and Jennifer H. Arlen, Reconsidering Efficient Tort Rules for Personal Injury: The Case of Single Activity Accidents, 32 WM. \& MARY L. REV. 41 (1990).) In Fletcher's view, the absence of liability for nonnegligent injuries in most cases represents just this calculation, whereas in typical cases of strict liability in tort-involving ultrahazardous activities, for example-the victim is not implicitly compensated because she will ncver impose a similar risk on the injurer. In other words, Fletcher urges us to think of tort victims as being engaged in long-term relationships with their injurers. Periodically, over the course of the relationship, the victims and injurers switch roles. From an ex ante perspective, the harms and benefits of the relationship might be expected to come out even in the long run. Of course, from the ex post perspective of a given victim who has suffered extensive harm (or a given injurer who has never suffered but only imposed harm), this purely probabilistic form of reciprocity may be small consolation. The ex post accident victim will notice that in this context the law attends to reciprocity of costs and benefits not at the level of any given individual but only at the level of the "community" of drivers.

Indeed, any negligence or cost-benefit standard can be understood as aggregating the benefits of saved precautions enjoyed by the defendant together with the costs suffered by third parties-provided that "harm" is initially defined in a strict liability sense. The idea is that instead of looking at harm in isolation, as does strict liability, negligence standards aggregate injurers and victims into a single group for purposes of calculating net harm. For a similar example, starting from the assumption that unintentional harm is legally cognizable and discussing discriminatory purpose in race equal protection, see infra notes 150-155 and accompanying text. 
dinner regularly, but $A$ moves into $B$ 's house and $B$ often borrows $A$ 's car. At this stage of the relationship, it may make sense for the two of them to divide labor and specialize in their contributions to the relationship, maintaining aggregate equality within the frame of the relationship as a whole but not within the smaller frames of dining, housing, and transportation. That is, $A$ and $B$ could agree that $A$ pays for all dinners and provides the car, while $B$ pays the mortgage. Eventually, $A$ and $B$ might become partners and make multiple exchanges of this sort entirely implicit-or perhaps even irrelevant, if the goal of the relationship becomes maximizing joint utility without regard to the separate, solely self-regarding utility of either individual. At this stage, $A$ and $B$ would be committed not just to each other but to group aggregation of utility. ${ }^{48}$

\section{Why and Where Framing Matters}

We have seen that while private law ordinarily focuses on discrete, individuated interactions, some legal rules and regimes are willing to aggregate interactions into larger transactional units along one or more of three dimensions. Based on our observations of the patterns of smaller and larger transactional frames in private law, we might take away two lessons that will be illuminating when we turn to public-law cases.

The first is about where and to what extent manipulation of transactional frames is possible. The more that parties are engaged in repeat-play relationships over time, and the broader the scope of these relationships, the more room exists for aggregation. Where parties have only isolated or occasional interactions with one another, and where these interactions are narrow in scope, there will be little room for aggregation. Focusing on the scattered pockets of aggregation over time and scope in private law should not distract us from the fact that most of the interactions governed by private-law legal regimes more closely resemble $A$ and $B$ 's miserable blind date than their cooperative long-term relationship. In the typical tort case, for example, the possibilities for individual-level aggregation will be limited to the kinds of offsetting benefits contemplated by the Restatement, such as the occasional monetary windfall for a defamation plaintiff. ${ }^{49}$

The possibility of aggregating over groups probably also depends on the existence of relationships, although in a somewhat different, and difficult to capture, sense. Group aggregation usually becomes conceivable only where individuals are connected through special social, economic, or

48. Cf. GaRy S. BECKER, A TREatise ON THE Family 82 (1981) (defining "love" as the inclusion of someone else's preferences in one's utility function).

49. See supra text accompanying note 44 . 
cultural bonds that create some sort of collective identity. Without attempting to elaborate on the conditions under which group-level assessments of harm will seem appropriate, we might simply recognize that group aggregation most often emerges as a possibility in legal regimes concerned with equal treatment of socially salient groups such as racial minorities and women. In the vast majority of private-law cases, group aggregation, while possible in theory, simply does not strike anyone as a live option. ${ }^{50}$

The second lesson is about when enlarging transactional frames will make a difference. Allowing offsetting benefits to be brought into transactional frames will only matter where offsetting benefits exist and, slightly less obviously, where restitution for benefits would be unavailable in a separate transaction. First of all, the significance of aggregation is limited with respect to most interactions involving private parties because private parties rarely confer uncompensated benefits on one another. Of course, private parties benefit one another all the time, but most of these benefits are compensated in market transactions. Contracting parties invariably expect to benefit from the contractual exchange, but the expected benefit is mutual; no one expects to walk away a net loser. ${ }^{51}$ Only where one party has behaved altruistically (for example, by bestowing a gift) or has generated substantial positive externalities (for example, in the case of a large business enterprise that generates economic growth in the surrounding community) will there be much in the way of benefits to offset.

But let us assume the existence of some benefits. The significance of allowing these benefits to be offset against harms in a single transaction depends on whether the alternative is separate transactions for harms and benefits; or whether, as is often the case, the alternative is a separate transaction for harms and no transaction for benefits. Legal regimes often treat harms and benefits asymmetrically, offering much more generous compensation for harm than restitution of benefits. ${ }^{52}$ As a result, the decision of whether to broaden a transaction to allow the defendant to offset benefits conferred on the plaintiff is often dispositive of whether those benefits will ever count in the defendant's favor. For example, suppose a generous handyman decides to paint his neighbors' house while they are

50. Private-law rules that resort to aggregation across groups with no independent social significance, such as the ones discussed supra text accompanying notes 30-35, are the exception, not the rule.

51. In theory, we might look for benefits in producer or consumer surplus. See David Rosenberg, Individual Justice and Collectivizing Risk-Based Claims in Mass-Exposure Cases, 71 N.Y.U. L. REV. 210, 243 (1996) (suggesting that one could offset the harm inflicted on consumers by manufacturers in products liability cases by the consumer surplus they derive from the harmcausing product).

52. See, e.g., Saul Levmore, Explaining Restitution, 71 VA. L. REV. 65, 65-66 (1985) (noting this asymmetry). 
away on vacation, but then, later that week, negligently fails to prevent one of his trees from falling on the freshly painted house. When the neighbors return and sue, if the handyman cannot offset the value of the paint job against the tree damage by combining them in a single transaction (as he probably cannot), he will never recover for it. This is because his separate suit for restitution is a sure loser. The same is true of the polluting cement factory, which has no hope of recovering in restitution from residents of the community for the economic benefits they enjoy from its operations there, and of the barge owner in the bridge case, who has no hope of recovering in restitution for the increased demand enjoyed by the mainland businesses. Compare the situation of the generous physician who provides lifesaving treatment to an unconscious person at the scene of an accident but, as she rushes away from the accident scene, negligently runs over her patient and (re)inflicts severe injury. When the double-victim sues her in tort, the physician probably will not be able to bring together the benefits of her initial treatment and the damages resulting from her negligent driving in a single transaction. Nevertheless, the physician probably will be able to recover the value of her services in a separate claim for restitution. ${ }^{53}$ So long as her benefits are ultimately counted, the physician should be close to indifferent. Where restitution for benefits is available, therefore, much less turns on whether courts are willing to aggregate: The choice is merely between one big transaction and two small ones.

In sum, legal regimes governing the interactions of private parties offer limited opportunities to enlarge transactional frames through techniques of aggregation. (Some of these limits are theoretical, others just practical or intuitive.) The paradigm cases governed by common-law and other privatelaw rules are simple, discrete contacts or contracts between individuals who have no further relationship. The size and shape of transactions in such cases are self-evidently narrow. Much of the preceding discussion has highlighted marginal cases in which a thicker relationship between or among individuals allows for the possibility of expanding transactional frames by aggregating harms and benefits over time, scope, or group. In general, however, the scarcity of repeat-play relationships of significant duration and scope, the commitment to individualized assessments of harm, and the insignificance of unrecovered benefits render the question of how to frame transactions of limited importance in private law.

Moreover, to the extent framing questions are important in private-law regimes, they tend to be answered self-consciously and instrumentally, in

53. Compare Mohrv. Williams, 104 N.W. 12 (Minn. 1905), in which the court suggested that the damages owed by the physician-defendant to the patient-plaintiff for performing a surgical procedure on her left ear after she had consented to a similar procedure on her right ear should be offset by the medical benefits of the operation. Here, the benefit and harm were closely enough linked in time and scope to be combined in a single transaction. 
light of the goals and mechanisms of the relevant legal regime. For example, the extent to which marriage law should aggregate interactions between spouses over time and scope within a broader transactional frame is a subject of explicit debate in the scholarly literature. Proponents of limited legal intervention, or a broader transactional frame, emphasize the high administrative and relational costs of allowing spouses to impose tort or contract sanctions on each other for adultery or other discrete instances of marital misbehavior. ${ }^{54}$ Likewise, economic justifications for group aggregation in economic loss cases follow straightforwardly from the pursuit of allocative efficiency. ${ }^{55}$ To be sure, the relevance of offsetting benefits has not been fully theorized across all areas of private law, and unresolved aggregation and framing puzzles no doubt persist. But the more limited significance of offsetting benefits generally in private law combined with the more explicit attention to instrumental goals makes framing transactions relatively unproblematic when private parties are on both sides of transactions.

\section{FRAMING CONSTITUTIONAL TRANSACTIONS}

Many public-law regimes, governing interactions between government and private parties, borrow the common-law model of transactional harm. Here too, rules and adjudication revolve around self-contained, discontinuous collisions between government and some private individual or group. ${ }^{56}$ The collision pushes the private party away from some baseline level of welfare, inflicting some amount of "harm" measured by the downward departure from this baseline. And the corrective goal of adjudication is to maintain background distributive neutrality by restoring the pretransactional level of welfare. ${ }^{57}$ No less than in common-law cases, application of this model in public-law cases depends upon a well-defined transaction. Unlike in private law, however, the appropriate frame for public-law transactions is seldom self-evident. As we have seen, private law generates difficult transactional framing decisions at the margin. But every public-law framing case is hard. The problem of framing transactions is at

54. See Posner, supra note 18; Scott \& Scott, supra note 23; see also Margaret F. Brinig \& Steven M. Crafton, Marriage and Opportunism, 23 J. LEGAL STUD. 869, $892-94$ (1994) (contemplating the possibility of allowing spousal claims for compensation or restitution within a contractual framework).

55. See Bishop, supra note 35. And inasmuch as we are interested in piercing the positivist veil, the choice between strict liability and negligence-where negligence is understood as group aggregation of strict liability harms - has, of course, been exhaustively analyzed by economists in terms of efficient precaution-taking, activity levels, and the like. See, e.g., STEVEN SHAVELL, ECONOMIC ANALYSIS OF ACCIDENT LAW (1987).

56. Or occasionally a different government entity, as in separation of powers and federalism contexts. See infra Section III.H.

57. Sunstein, supra note 15 , at 282. 
the core of public-law cases because when government is on one (or both) sides of a transaction, there is vastly greater room for aggregation and framing, and often vastly more at stake.

Because citizens are always in a repeat-play-or, more accurately, a continuous-play-relationship with government, opportunities for aggregation over time are ubiquitous. What if the middle-aged homeowner whose property is taken by government without on-the-spot compensation nevertheless was implicitly compensated by the Head Start benefits he received as a child and the Medicare payments he can look forward to after retirement? Because citizens interact with government across such a broad range of activities and institutions-education, public health, policing, transportation, national defense, and the taxation necessary to fund these and numerous other public goods-the possibilities for aggregation in scope are also virtually unlimited. A city government that operates inferior schools in minority neighborhoods, while at the same time channeling welfare payments and extra police services to those neighborhoods, may be able to make a plausible case that its policies have not imposed a disparate impact. Finally, because government often interacts with citizens at the level of groups, and because socially salient groups like racial minorities and women play a much larger role in public law, opportunities for group aggregation abound. Even if the aforementioned city government convincingly demonstrates that its different treatment of minority neighborhoods is, on balance, equal, it will never be able to demonstrate that each resident of the minority neighborhood has received the same net benefits as each member of the majority neighborhood. Whether the government's policy should count as equal, therefore, will depend on whether equality must be determined at the level of the individual or the level of the group, ex ante or ex post. The bottom line is that constitutional and statutory regulations of government transactions, unlike legal regimes affecting only private parties, always have the option of aggregating costs and benefits over time, scope, or group instead of focusing on discrete, individualized interactions. Transactional frames in public law are always up for grabs.

Moreover, unlike private parties, government provides its citizens with innumerable benefits: advantageous laws and regulations, spending programs, direct provision of public goods, and the like. Citizens do, of course, pay for some of these benefits through taxes. But because governmental benefits and tax burdens are seldom perfectly aligned, and because total benefits may surpass the total tax burden, many citizens and groups of citizens receive benefits in excess of their tax payments. ${ }^{58}$

58. Saul Levmore, Just Compensation and Just Politics, 22 CONN. L. REV. 285, 290-93 (1990). 
Furthermore, there is usually no mechanism equivalent to private restitution through which government can extract compensation from the recipients of these benefits. Government does occasionally employ user fees and special tax assessments to match financial burdens more closely to benefits. But many government benefits remain "free" to a set of citizens who derive all or most of the value without paying the full price in taxes. ${ }^{59}$

The only nonpolitical way that government can receive credit for such net benefits is to bring them within a transactional frame in order to offset harms ${ }^{60}$ For example, by widening the access road to a shopping mall, a city government benefits the owners of the mall by increasing the number of shoppers. Ordinarily, the city will get no credit for providing this benefit (other than the political goodwill of the mall owners and shoppers). ${ }^{61}$ But now suppose that some of the land needed to widen the road was owned by the shopping mall and acquired by the city using its eminent domain power. The city may now be able to reduce the amount of compensation owed to the mall owners by the economic benefits they derive from the new road. ${ }^{62}$ Along the same lines, the city government will not get any nonpolitical credit for providing cash grants to artists, but if it also attempts to censor the work of these artists by selectively denying funding for indecent projects, it may be able to defend itself against a free speech challenge by arguing that the benefits of funding should be aggregated with the harm of the indecency restriction into a unified transaction or "program" that does not violate the First Amendment. ${ }^{63}$

For an exception that illustrates the general rule of asymmetry between government benefits and harms - and that also demonstrates the vastly greater room for aggregation over time, scope, and group in public lawconsider the recently settled litigation between state governments and tobacco companies. In the mid-1990s, state governments sued tobacco companies for smoking-related health care costs incurred through their

59. Id. For an overview of the extent to which government benefits are recaptured through taxes or fees, see WINDFALLS FOR WIPEOUTS (Donald G. Hagman \& Dean J. Misczynski eds., 1978); and Eric Kades, Windfalls, 108 YALE L.J. 1489 (1999).

60 . Of course, government actors to some extent receive political credit for benefits, just as they receive political blame for costs. An asymmetry arises outside of the political process, however, because government is often subject to constitutional or statutory liability for various kinds of costs, but seldom does it receive any comparable extrapolitical credit for benefits.

61. The government could, of course, impose an assessment on the mall's owners. Many commentators have suggested that government make greater use of such assessments in the landuse context. See WINDFALLS FOR WIPEOUTS, supra note 59; see also Daryl J. Levinson, Making Government Pay: Markets, Politics, and the Allocation of Constitutional Costs, $67 \mathrm{U}$. CHI. L. REV. 345, 418 (2000); Saul Levmore, Takings, Torts, and Special Interests, 77 VA. L. REV. 1333 1355-56 (1991). An elaborate scheme for government recompense of benefits to property owners is proposed in Abraham Bell \& Gideon Parchomovsky, Givings, 111 YALE L.J. 547 (2001).

62. The general doctrinal rule in takings law is that government can offset benefits directly stemming from the same project that resulted in the taking. See infra note 72 and accompanying text.

63. NEA v. Finley, 524 U.S. 569, 585 (1998). 
Medicaid programs. Given that government so seldom attempts to recover restitution for benefits through litigation, the lawyers for the states struggled to find a legal box that would accommodate their claims. The states were essentially seeking restitution for benefits they had provided to sick smokers, but from tobacco companies instead of from the Medicaid beneficiaries themselves. Ultimately, the states' best theory of the case was based on subrogation: The tobacco companies were privately liable to smokers for their medical expenses, and the government, having "paid" the smokers for these expenses, was now stepping into their shoes to recover from the tobacco companies. On this theory, the states were seeking restitution for the benefit of indemnifying tobacco companies for their liability to sick smokers. ${ }^{64}$

Notice how unusual it is for the government to litigate restitution for benefits in this way. The federal and state governments have never expressed any interest in seeking restitution from tobacco farmers for, say, crop subsidies or the fruits of government-funded agricultural research. And of course if government sought restitution from all Medicaid beneficiaries, that would just defeat the redistributive purposes of the program. As mentioned previously, government occasionally does recoup benefits using special assessments, and presumably, political concerns aside, government simply could have taxed the tobacco companies the same amount they hoped to recover in litigation. But ordinarily, the net beneficiaries of government regulation or spending-after accounting for all taxes, special assessments, and user fees-are left to enjoy their windfalls with impunity. The tobacco litigation should be understood as the exception that proves this rule. In virtually every other context, the government's only hope of getting credit for benefits in litigation is to aggregate them with costs in a single transactional frame.

Bracketing the oddity of government suing private parties for restitution, let us turn our attention to the exchange of costs and benefits between tobacco companies and government over the course of their relationship. In response to the states' Medicaid reimbursement claim, the tobacco companies raised the argument that the state governments are actually net economic beneficiaries in their dealings with tobacco. ${ }^{65} \mathrm{By}$ killing off smokers before they can consume pension, Medicare, nursing home, and social security benefits, and by paying substantial excise taxes, tobacco companies contribute substantial sums of money to government

64. Hanoch Dagan \& James J. White, Governments, Citizens, and Injurious Industries, 75 N.Y.U. L. REV. 354, 382-405 (2000) (conceptualizing the litigation this way).

65. Cf. United States v. House, 808 F.2d 508 (7th Cir. 1986). In that case, a convict who murdered a fellow prisoner and was ordered to reimburse the government for the victim's funeral costs claimed that he should be permitted to offset the much larger financial windfall he had conferred on the government by saving it the costs of feeding and housing the victim. While recognizing that "chutzpah sometimes pays off," id. at 509 , the court rejected the offset. 
accounts-perhaps even more than they cost these accounts in the form of health care benefits for sick smokers. ${ }^{66}$ This offsetting-benefits argument raises the vexing question of how big and what shape a slice of the ongoing relationship between tobacco companies and the government should be considered in toting up tobacco externalities. How much, in other words, should we aggregate over time and scope in framing the relevant transaction between government and the tobacco companies?

Had the cases actually been litigated, the state governments doubtless would have attempted to circumscribe the relevant transaction to exclude offsetting financial benefits related to smoking. Following the Restatement of Torts approach, ${ }^{67}$ state governments would have argued that excise tax payments and pension benefits, at least, should not be counted because they relate to different "interests" than medical expenditures (or they affect different government "programs," are not "germane," lack a subject matter "nexus," or the like). A bolder strategy on the part of the states, however, would have been to expand the transaction to encompass more of its own benefits. Aggregating over time, states could point to countless benefits conferred on the tobacco industry throughout its history, ranging from antebellum assistance to slaveowners in tobacco-growing states to the promulgation and enforcement of corporate law. Even within a given time slice, states might aggregate over scope, invoking benefits received by the shareholders, employees, and customers of tobacco companies, ranging from such "general" benefits as highways, schools, and police, to "special" benefits, like price supports for tobacco farmers. ${ }^{68}$ Of course, once the transactional frame is stretched this far in time and scope, the tobacco companies could catalog additional offsetting benefits of their own, starting with the property, sales, and income tax revenues resulting from their operations.

Clearly, the further the transactional frame expands, the more difficult it is to generate an accurate empirical assessment of net costs and benefits. At the limit, this accounting enterprise devolves into radical indeterminacy. How can we possibly answer the questions of whether the R.J. Reynolds company is better off or worse off, and by how much, on account of its dealings with the State of North Carolina? Compared to what? How the company would have fared in a different state? In the state of nature? If a complete accounting is impossible, though, questions of how to cabin the relevant transaction become crucially important, because the result of

66. The empirical accounting of costs and benefits is controversial. For a quick survey of the literature, see Jon D. Hanson \& Kyle D. Logue, The Costs of Cigarettes: The Economic Case for Ex Past Incentive-Based Regulation, 107 Y ALE L.J. 1163, 1232-36 (1998).

67. See supra text accompanying note 44.

68. The distinction between "general" and "special" benefits sometimes plays a role in takings cases. See infra note 72 . 
litigation will depend on which costs and benefits are counted. Against the background of the enduring and multifaceted relationship between government and tobacco companies, it seems perfectly arbitrary to perform an accounting of net externalities based only on temporally proximate health expenditures and excise taxes. All of the other costs and benefits are just as real; why count some but not others? Is there any nonarbitrary set of principles that would determine the right way to frame the relevant transaction?

Unfortunately, this quandary is not an artifact of the unusual situation in which the government sues private parties for recoupment of benefits. The very same transactional framing issues would arise if, for example, a tobacco company were litigating a takings claim against the government, seeking just compensation for a condemnation of, or regulatory harm to, its property. Now it would be government in the first instance emphasizing the offsetting benefits it had provided to the tobacco companies, which might count as implicit compensation, but the overall accounting problems would be just the same.

The general point is that any claim of government-inflicted harm (or, in the oddly inverted tobacco litigation, benefit) requires an explicit or implicit decision about how to slice up the continuous relationship between government and its citizens into a discrete transaction. The size and shape of the transactional slice will determine the extent to which government benefits can be offset against harms and, therefore, whether government has inflicted a net injury. As the tobacco litigation demonstrates, government can always point to some benefits that would offset the localized harms if they were brought into the same transactional frame and that cannot be recaptured through the litigation process in any other way. The extent to which these benefits can be used to offset harms, and therefore the scope of government liability for statutory and constitutional violations, depends entirely on the position and expanse of the transactional frame.

By now it should be easy to understand why constitutional law is haunted by the problem of how to frame transactions. Constitutional violations are commonly understood in terms of government's infliction of a qualitative type of harm on some individual (or, much less commonly, group) by way of a discrete transaction. This model of transactional harm is reflected in the conventional understanding of constitutional rights: as individual entitlements that trump collective decisionmaking, the violation of which inflicts a self-contained harm on the individual rights-bearer. ${ }^{69}$

69. See, e.g., RONALd DWORKIN, TAKING RIGHTS SERIOUSLy 184-205 (1977). For useful discussions and criticisms of the prevalence of this view in constitutional law, see Richard $\mathbf{H}$. Pildes, Why Rights Are Not Trumps: Social Meanings, Expressive Harms, and Constitutionalism, 27 J. Legal STUD. 725 (1998); and RODERICK M. Hills, JR., THE CONSTITUTIONAl Rights OF 
(Constitutional rights proscribing "unequal" or "nonneutral" treatment are also premised on the significance of transactional harm, but with the baseline from which harm is measured shifted to the treatment of some other reference individual or group.) As we have seen, however, the very idea of government "inflicting harm" on someone has meaning only within some transactional frame. Any standard of constitutional liability that relies on harm-inflicting transactions will turn on the expanse and position of the frame being employed. Unfortunately, even as courts and commentators shrink and stretch transactional frames to create or negate constitutional liability, questions of how constitutional transactions should be framed are seldom asked, let alone answered, by constitutional doctrine or theory.

The remainder of this Part demonstrates how transactional framing questions arise in virtually every area of constitutional law and shows that the answers to these questions are never obvious or determinate in theory, even where they seem to be in practice. ${ }^{70}$ Each of the constitutional norms discussed in the survey of constitutional law and theory that follows is commonly conceptualized by courts and theorists as preventing a certain type of transactional harm. Predictably, each is afflicted with similar ambiguities and inconsistencies about the appropriate placement of transactional frames. This Part seeks to establish that the problem of transactional framing is endemic to constitutional law as currently conceived.

\section{A. Takings}

Some government programs that reduce the wealth of individual property owners count as constitutionally cognizable "takings" for which just compensation is required. Compensation usually takes the form of an on-the-spot cash transfer from government. Courts and commentators have long puzzled, however, over the possibilities and limitations of implicit compensation for takings in the form of offsetting benefits. In nineteenthcentury railroad eminent domain cases, for example, just compensation for the value of land taken was routinely reduced by the amount of the increase in value that accrued to the remainder of the parcel. ${ }^{71}$ Courts continue to take account of offsetting benefits, but only sporadically and unpredictably.

Private Governments 7-12, 33-44 (Univ. of Mich., Pub. Law \& Legal Theory Research Paper No. 00-002, 2001), http://papers.ssm.com/paper.taf?abstract_id=258629.

70. This Part's exclusive attention to transactional-harm-based understandings of constitutional rights is in no way meant to deny the existence of alternative understandings of these rights, which are discussed later in the Article, see infra Section IV.B, or to offer a complete account of the framing choices embedded in the doctrine. The discussion that follows is simply meant to demonstrate the prominence, if not predominance, of the transactional harm model and to illustrate the pervasiveness of its attendant framing problems.

71. See William A. FISCHEL, REgulatory TAKINGS 80-84 (1995). 
The most that is clear in modern takings law is that the government can sometimes offset benefits to the condemnee that stem from the very same "project," "program," or "regulation" that effected the taking..$^{72}$ Thus, if a municipal government takes a few feet of an owner's commercial property to widen a road, the government may be able to offset the benefit of more customer traffic to the owner's store against the value of the lost land in determining how much cash compensation is owed. This relatively modest form of aggregation resembles tort law's occasional willingness to offset benefits conferred by the defendant against damages stemming from the same narrowly defined interaction.

In cases involving regulatory takings, though, courts and commentators have intermittently appealed to more expansive understandings of implicit compensation. Doctrinally, the Supreme Court sometimes invokes the idea of "average reciprocity of advantage" to deny compensation altogether for regulatory takings. ${ }^{73}$ In its original and narrowest form, reciprocity of advantage means that a land use regulation burdening a landowner will not count as an uncompensated taking if the same regulation confers roughly equal benefits on the same property owner. This is what Justice Holmes had in mind when he considered an offsetting benefits argument in the famous case of Pennsylvania Coal Co. v. Mahon. ${ }^{74}$ The argument foundered on the facts of that case, for the coal companies that suffered the economic burden enjoyed none of the regulatory benefits. ${ }^{75}$ Nevertheless, the reciprocity-of-

72. See, e.g., United States v. Miller, 317 U.S. 369, 377 (1943); United States v. Sponenbarger, 308 U.S. 256, 266-67 (1939); Donald L. Elliott, Givings and Takings, LAND USE L. \& Zoning DiG., Jan. 1996, at 3; Note, Condemnations, Implicit Benefits, and Collective Losses: Achieving Just Compensation Through "Community," 107 HARv. L. REV. 696 (1994).

Sometimes the issue of offsetting benefits is resolved in terms of "special" or "general" benefits. The former, but not the latter, can be offset by government. See Bauman v. Ross, 167 U.S. 548, 574-75 (1897); Elliott, supra, at 7. The leading treatise defines these terms as follows: A special benefit arises "from the peculiar relation of the land in question to the public improvement," whereas a general benefit arises "from the fulfillment of the public project which necessitated the taking." 3 JULIUS L. SACKMAN, NICHOLS ON EMINENT DOMAIN $\$ 8 A .02[4]$, at $8 \mathrm{~A}-32$ to -33 (3d ed. 2000 ).

73. The evolution of the case law is described in Raymond R. Coletta, Reciprocity of Advantage and Regulatory Takings: Toward a New Theory of Takings Jurisprudence, 40 AM. U. L. REV. 297, 304-45 (1990); and Lynda J. Oswald, The Role of the "Harm/Benefit" and "Average Reciprocity of Advantage" Rules in a Comprehensive Takings Analysis, 50 VAND. L. REV. 1449, 1489-522 (1997).

74. 260 U.S. 393 (1922). In Mahon, a state statute prohibited coal mining companies from mining underneath a surface owner's property in such a way as to cause sinking of the surface land. In effect, this required miners to leave in place pillars of coal to support the land aboveeven when, as in Mahon, the coal-mining company had previously purchased the support rights from the surface owner. The Supreme Court, in a famous opinion by Justice Holmes, held that the statute had effectuated an uncompensated taking from the mining company by going "too far" in diminishing the value of its subsurface property interests. Id. at 415 . In reaching this conclusion, Holmes rejected the possibility that the state could avoid paying compensation because of the "average reciprocity of advantage" created by the statute, $I d$.

75. See Richard A. Epstein, Takings: Descent and Resurrection, 1987 SUP. CT. REV. 1, 22-23 (advancing this interpretation of Holmes's Mahon opinion). 
advantage idea suggested that courts might eliminate the need for compensation in regulatory takings cases by broadening the transactional frame to take account of offsetting benefits to the burdened property owner.

Courts have made good on this promise. In upholding comprehensive zoning ordinances against takings challenges by owners of restricted parcels, for example, courts have emphasized the offsetting benefits to these owners, in the form of increased property values resulting from the similar restrictions applied to neighboring parcels. ${ }^{76}$ For a more generous application of the same principle, consider the Shanghai Power case, in which an American corporation whose foreign investment was confiscated by the Chinese government had its claim against China extinguished by the U.S. President in the process of establishing diplomatic relations with China. ${ }^{77}$ The court decided there had been no compensable taking by the United States, in part because the plaintiff would benefit in the long run from the enhanced opportunities for foreign trade resulting from the President's establishment of good relations with China. ${ }^{78}$ Invoking reciprocity of advantage in cases like this allows courts to defeat takings liability by generously aggregating and offsetting regulatory costs and benefits over time and scope, at least within the confines of a single statute or regulatory program. ${ }^{79}$

Sometimes the reciprocity-of-advantage principle is expanded to contemplate aggregation over groups as well. In Penn Central Transportation Co. v. New York City, the Court rejected a takings challenge to a New York City landmark preservation law that prevented the owners of Grand Central Terminal from building an office tower on top of the terminal. ${ }^{80}$ In explaining why the huge economic loss to the owners of the terminal did not warrant just compensation, the Court emphasized the

76. See Oswald, supra note 73, at 1506-10.

77. Shanghai Power Co. v. United States, 4 Cl. Ct. 237 (1983). The case is discussed in Dagan \& White, supra note 64, at 413-14.

78. Shanghai Power Co., 4 Cl. Ct. at 246.

79. The persuasiveness of the reciprocity argument in these cases, taken on its own terms, depends on how much precision is demanded in the accounting of costs and benefits. Only on a very rough accounting should we expect any particular landowner adversely affected by some aspect of a zoning scheme to enjoy enough benefits from that scheme to come out even in the end. For an example of accounting practices that blur the line between approximation and fiction, consider Justice Brennan's dissenting opinion in Nollan v. California Coastal Commission, 483 U.S. 825, 842 (1987). In that case, California had conditioned issuance of a building permit for a beachfront house on the owner's consent to an casement that would allow the public to walk on his beach. (Nollan is discussed as an unconstitutional conditions case, infra notes 113-118 and accompanying text.) Arguing that this did not amount to an uncompensated taking, Brennan pointed to the offsetting benefits to the owner in the form of reciprocal permission to walk along the beaches of other homeowners from whom the state had extracted similar easements. Id. at 856 . Needless to say, most self-interested owners of beachfront property would hesitate before swapping public access to their private beaches for reciprocal access to the (mostly nonexistent) private beaches of the public.

80. 438 U.S. 104 (1978). 
offsetting economic and "quality of life" benefits of landmark preservation. ${ }^{81}$ These benefits would hardly be sufficient to compensate the owners for their enormous economic loss; as the Court recognized, the owners may have been personally "more burdened than benefited" by the landmark preservation law. ${ }^{82}$ Nevertheless, the Court suggested, average reciprocity of advantage might obtain at the level of "all New York citizens," a group that includes the beneficiaries of historic preservation along with the immediate economic losers. ${ }^{83}$ As long as the benefits of regulation are at least equivalent to the costs across all members of this group, the argument would go, there has been no taking requiring compensation. The distribution of costs and benefits within the group, on this theory, is of no consequence: Benefits and burdens need not net out nonnegative at the level of any particular individual. ${ }^{84}$

When courts license generous aggregation over time, scope, and group simultaneously, takings frames can become very broad indeed. In Keystone Bituminous Coal Ass' $n$ v. DeBenedictis, for example, the Court decided that a regulation similar to the one at issue in Mahon, requiring coal companies to maintain surface support, did not amount to an uncompensated taking. ${ }^{85}$ Expanding upon Holmes's reciprocity-of-advantage theory from Mahon, the Keystone Court suggested that the economic burden imposed by the regulation on coal companies might be offset not just by the benefits to surface owners and to others in the "public at large," but also by benefits to the coal companies themselves stemming from other government laws or regulations. ${ }^{86}$ As in Penn Central, the Court in Keystone seems willing to aggregate over groups, lumping coal companies together with surface owners and the general public. Simultaneously, the Court seems to endorse a much more generous form of aggregation over time and scope, contemplating government benefits outside of this particular regulatory program. Either one of these aggregation moves would be sufficient to do

81. Id. at $134-35$.

82. Id. at 135.

83. Id. at 134.

84. Compare Justice Rehnquist's dissent, which emphasizes the absence of reciprocity at the individual level. Id. at 147-50 (Rehnquist, J., dissenting).

85. 480 U.S. 470 (1987). The basic facts of Mahon are recounted supra note 74.

86. Keystone, 480 U.S. at 491 . According to the majority opinion, "Under our system of government, one of the State's primary ways of preserving the public weal is restricting the uses individuals can make of their property. While each of us is burdened somewhat by such restrictions, we, in turn, benefit greatly from the restrictions that are placed on others." Id. In an accompanying footnote, the majority expanded on its endorsement of group aggregation, using an analogy to taxation:

The Takings Clause has never been read to require the States or the courts to calculate whether a specific individual has suffered burdens under this generic rule in excess of the benefits received. Not every individual gets a full dollar return in benefits for the taxes he or she pays; yet, no one suggests that an individual has a right to compensation for the difference between taxes paid and the dollar value of benefits received.

Id. at $491 \mathrm{n} .21$. 
away with liability for virtually any regulatory taking. Calculating net effects at the level of the public at large would insulate any regulation whose overall benefits might plausibly exceed overall costs. And not much creativity is required to locate any number of additional beneficial government policies - in the past, present, or future - that could be included within the frame to offset the burdens imposed by this particular regulation. A court that is willing to expand the transactional frame this far along all three dimensions might as well just presume that the long-term benefits of government actions of various sorts will advantage all citizens more than they are harmed by any particular regulation that might be challenged as an uncompensated taking. ${ }^{87}$ All that remains is the nagging question of when and why courts will choose to frame away liability for takings.

Similarly, the scholarly literature on takings displays virtuosity in the tricks of the transactional frame. Scholars seeking to limit government's liability for takings in a particular context aggressively aggregate offsetting benefits in time and scope or strategically switch to group-level analyses. Should zoning regulations that restrict the conversion of farmland trigger government compensation? No, because the owners of farmland have received offsetting benefits in the form of farm subsidy programs, mortgage deductions, and environmental restrictions on surrounding properties, not to mention the "numerous economic and social regulations designed to facilitate commerce and protect citizens from the harmful consequences of economic activity." ${ }^{88}$ How much compensation does the City of Detroit owe when it condemns land in a Polish neighborhood for the construction of a new General Motors assembly plant ${ }^{89}$ Perhaps none, because in offsetting the economic benefits stemming from the plant against the dispossession and dislocation of residents, the argument goes, the relevant unit of analysis should be the Poletown neighborhood as a whole rather than each individual resident. ${ }^{90}$ Was the Supreme Court correct in PruneYard Shopping Center v. Robins ${ }^{91}$ to permit California lawmakers to "take" shopping center owners' rights to exclude political pamphleteers without paying compensation? Arguably so, for the social gains from expressive political activity may offset the costs to shopping center owners

87. See Epstein, supra note 75 , at $22-23$ (attributing this view to the Keystone Court and criticizing it).

88. Mark W. Cordes, Takings, Fairness, and Farmland Preservation, 60 OHIO ST. L.J. 1033 , 1072-77 (1999); see also Private Property Rights and Environmental Laws: Hearing Before the S. Comm. on Environment and Public Works, 104th Cong. 164-65 (1995) (statement of agricultural economist $\mathrm{C}$. Ford Runge) (summarizing empirical evidence that large landowners tend to be net winners from government activity affecting their land).

89. See Poletown Neighborhood Council v. City of Detroit, 304 N.W.2d 455 (Mich. 1981).

90. Note, supra note 72 , at 709 .

91. 447 U.S. 74 (1980). 
of losing their rights to exclude. ${ }^{92}$ At the extreme, these arguments point toward a general presumption that "over time the burdens associated with collectively determined improvements will have been distributed 'evenly" enough so that everyone will be a net gainer." ${ }^{93}$ So much for the Takings Clause.

Recognizing the slippery slope toward unlimited expansion of the takings transactional frame and, consequently, Keystone-style permission for government to redistribute wealth and property rights at will, scholars inclined to resist such conclusions advocate strict transactional boundaries. The most sustained argument is provided by Professor Epstein, who insists that aggregation over time and scope (in his terminology, "step transactions" ${ }^{94}$ ) be limited to individual statutes or "programs." ${ }^{95}$ Suppose $\operatorname{tax} A$ redistributes wealth from person or group $X$ to person or group $Y$, and $\operatorname{tax} B$ redistributes exactly the same amount of wealth from $Y$ to $X$. If the legislature combines the two taxes into a single statute, then Epstein would conclude that the prima facie takings from $Y$ and $X$ (effected by taxes $B$ and $A$, respectively) were implicitly compensated by taxes $A$ and $B$, respectively, leaving the government with no further obligation to pay compensation. But if taxes $A$ and $B$ were passed as separate statutes, each would be evaluated independently and ruled an uncompensated taking. ${ }^{96}$

Epstein draws a clear line, ${ }^{97}$ but his justification for it remains anything but. Epstein's rationale for refusing to aggregate across the seemingly arbitrary boundaries of statutes consists mainly of the observation that costs imposed on an individual or group by one statute may not be fully offset by the benefits conferred on the same individual or group by other statutes over time or scope. ${ }^{98}$ But this is merely an argument against the presumption that benefits will offset burdens, not an argument against the

92. Lillian R. BeVier, Give and Take: Public Use as Due Compensation in Prune Yard, $64 \mathrm{U}$. CHI. L. REv. 71, 80-81 (1997).

93. Frank 1. Michelman, Property, Utility, and Fairness: Comments on the Ethical Foundations of "Just Compensation" Law, 80 HARV. L. REV. 1165, 1225 (1967) (emphasis omitted).

94. RICHARD A. EPSTEIN, TAKINGS 209 (1985).

95. Id. at 210. Epstein does not define "program."

96. Epstein might consider the two statutes "separate" even if their separation was exquisitely formalistic-for example, if the legislature became aware of tax $A$ 's redistributive consequences, quickly drafted amendment $B$ to offset perfectly the $X$-to- $Y$ redistribution, but, for arcane procedural reasons, had to pass amendment $B$ as a separate statute. See Thomas W. Merrill, Rent Seeking and the Compensation Principle, 80 Nw. U. L. REV. 1561, 1573 (1986) (reviewing EPSTEIN, supra note 94). Certainly if the statutes were further separated in time or in subject matter, Epstein would insist that the legislature pay compensation for each tax rather than allow them to offset.

97. This is not to say that the relevant costs and benefits stemming from a particular statute are clear. To the contrary, cases like Shanghai Power demonstrate the copious room for manipulating transactional frames that exists even within the limits of a single statute or regulatory program. See supra notes $76-79$ and accompanying text.

98. See EPSTEIN, supra note 94, at 210. 
calculation of net benefits and burdens within a larger transactional frame. Ultimately, Epstein's insistence upon constricted transactional frames rests on little more than the pained recognition that "[i]n the limit, a court could place all legislative initiatives past and future into a single hopper and proclaim that the benefits and burdens are always proportionate, thereby gutting the takings clause for general regulation." ${ }^{99}$ Epstein regards this as a reductio ad absurdum, but it is precisely the point of cases like Keystone and precisely the goal of scholars who press for more aggregation and broader transactional frames. To that audience, Epstein's insistence on framing transactions within the boundaries of particular statutes will continue to seem perfectly arbitrary. ${ }^{100}$

Epstein's theory of takings also seems to demand strict limits on group aggregation, though Epstein himself is never clear on exactly where the lines should be drawn. For example, he argues that although bankruptcy legislation effects a prima facie taking on a creditor whose recovery from the debtor is limited to cents on the dollar, the creditor is implicitly compensated by the reciprocal limitations placed on other creditors. ${ }^{101}$ Because creditors as a group will recover more money from the debtors than they would in unregulated competition with one another, bankruptcy laws provide implicit compensation for their abrogation of creditors' preexisting "right" to seek full recovery of their debts. As Epstein is well aware, bankruptcy laws often will not provide implicit compensation at the level of an individual creditor. The creditor who, in the absence of bankruptcy laws, would have won the race to execute against the debtor's estate and recovered the full amount of her debt will suffer an economic loss when bankruptcy laws are implemented. But in this context, Epstein is willing to offset the benefits to other creditors against the costs to this alpha creditor, aggregating over creditors as a group. In other contexts, however, Epstein's willingness to engage in group aggregation seems to disappear. In cases where a zoning scheme imposes significant costs on an individual landowner, for instance, Epstein does not even entertain the notion that these costs might be offset by the benefits of the scheme to neighboring

99. Id.

100. Lawson and Seidman follow Epstein in arguing that aggregation over time and scope must be limited by "germaneness." Gary Lawson \& Guy Seidman, Taking Notes: Subpoenas and Just Compensation, 66 U. CHI. L. REv. 1081, 1100-03 (1999). While admitting that "[i]t seems artificial to slice off one narrow piece of the system ... and view it in isolation, especially when the piece's contours may be determined largely by the shape of the whole," Lawson and Seidman see the need for a stopping point short of "view[ing] all governmental action as part of a unified scheme of organized government." Id. at 1101-02. As to why aggregation should not be extended to its logical limits and why government actions should be evaluated only in "germane" sets, however, Lawson and Seidman come up empty. They fall back on a normative gesture to "the principle of just compensation that would generally have been understood by an informed public in the late eighteenth century." Id. at 1102.

101. EPSTEIN, supra note 94 , at 224-28. 
landowners. ${ }^{102}$ What is the principle that makes aggregation over the group of creditors permissible but not aggregation over the group of neighbors? More generally, what is the principle that permits some kinds of group aggregation but stops short of Keystone-style aggregation over society as a whole? ${ }^{103}$

These questions would seem central to any normative theory of takings law that revolves around individual economic harm, yet they are seldom, if ever, identified as important, let alone answered persuasively. In any takings case, the transactional frame can be fit snugly around the application of a particular regulation to one property owner to create a picture of net harm. This picture can always be converted to one of no harm, or even a net benefit, however, by expanding the transactional frame along one or more of the three dimensions of aggregation. The size and location of the transactional frame thus determines whether we see an uncompensated taking or a (more than) fully compensated one. Courts and commentators routinely manipulate the frames around takings transactions to produce their preferred results, but seldom is a particular approach to framing even recognized as such, let alone justified or generalized.

\section{B. Unconstitutional Conditions}

Government often conditions the receipt of some discretionary benefit on the acceptance of a burden that it would be unconstitutional to impose directly. Sometimes these conditional offers are permitted on the intuitive theory that the greater power to withhold the benefit entirely includes the lesser power to offer it with conditions. ${ }^{104}$ Sometimes, however, they are not permitted, on the theory that government imposes an unconstitutional condition by "penalizing" the exercise of the relevant constitutional right. Built into the conceptualization of penalties attached to the exercise of constitutional rights is the familiar notion that government is forbidden to inflict harm on individuals with respect to constitutionally protected interests. The obvious puzzle in unconstitutional conditions cases is how government can inflict harm on an individual by presenting her with the choice of voluntarily exchanging a constitutionally protected entitlement for a benefit that the government is under no constitutional obligation to

102. See id. at 267-73.

103. Merrill poses similar questions in terms of ex ante versus ex post analysis. See Merrill, supra note 96 , at 1572 ; cf. supra note 41 (discussing the interchangeability of group aggregation and ex ante terminology).

104. This view was famously expressed by Holmes in a number of cases. See, e.g., McAuliffe v. Mayor of New Bedford, 29 N.E. 517, 517-18 (Mass. 1892) (rejecting a policeman's complaint that he was unconstitutionally fired for expressing his political views on the theory that the policeman " may have a constitutional right to talk politics, but he has no constitutional right to be a policeman. ... [H]e takes the employment on the terms which are offered him"). 
provide in the first place. Presumably, individuals will choose to surrender their constitutional entitlements only when the government benefit has greater value to them-that is, in situations where they receive at least implicit compensation and walk away from the transaction better off than they were before the government's offer was presented. How, then, can a transaction with government that can only improve the welfare of the offeree inflict a constitutionally cognizable harm? ${ }^{105}$

Unconstitutional conditions cases strike many lawyers as uniquely perplexing, but they are nothing more than vivid examples of the general problem of framing transactional harm. The persistent puzzle in these cases is when and why individuals who choose to surrender constitutional entitlements are not implicitly compensated by the government benefits that they accept in exchange. ${ }^{106}$ Should the discretionary benefit be aggregated with, and offset against, the harm of surrendering the constitutional entitlement, or should the benefit and harm be framed and evaluated separately?

Consider a paradigmatic case: The federal government offers Medicaid funding to cover the medical expenses associated with childbirth but not the costs of getting an abortion. ${ }^{107}$ According to the Supreme Court, this is a permissible "refusal to subsidize" the exercise of the constitutional right to abortion rather than an impermissible "penalty" on the abortion right. At the same time, if the federal government denied all welfare benefits to women who chose abortion, or if a state refused to issue them driver's licenses, this would probably count as an unconstitutional penalty. ${ }^{108}$ Why

105. For especially useful overviews of the problem, in addition to the sources cited infra note 106, see ALAN WERTHEIMER, EXPLOITATION (1996); Seth F. Kreimer, Allocational Sanctions: The Problem of Negative Rights in a Positive State, 132 U. PA. L. REv. 1293 (1984); and Robert Nozick, Coercion, in PHLLOSOPHY, SCIENCE, AND METHOD 440 (Sidney Morgenbesser et al. eds., 1969).

106. As an initial matter, some apparent unconstitutional conditions cases can be reconceptualized so that this question ceases to be relevant and the puzzle disappears. Where third parties may be affected by the exercise or nonexercise of an individual's constitutional rights, for example, the "inalienability" of constitutional entitlements that are not entirely "owned" by an individual rightholder offers a straightforward explanation of why the transaction should be prohibited. See Cass R. Sunstein, The Partial Constitution 303-04 (1993); Thomas W. Merrill, The Constitution and the Cathedral: Prohibiting, Purchasing, and Possibly Condemning Tobacco Advertising, 93 Nw. U. L. REv. 1143, 1153-57 (1999). In another category of apparent unconstitutional conditions cases, the overriding concern seems to be equality of treatment. For example, the government clearly is not permitted to provide discretionary funding or tax exemptions to Republicans but not Democrats. Because the government misbehaves in these cases just by virtue of offering a benefit to some but not others, the unconstitutional conditions puzzle never arises. See Louis Michael SEIDMAN \& MARK V. TUSHNET, REMNANTS OF BELIEF 82 (1996); SUNSTEIN, supra, at 304. Many unconstitutional conditions cases, however, defy explanation in terms of third-party effects or equality. This is the residual category of true unconstitutional conditions cases.

107. See Harris v. McRac, 448 U.S. 297 (1980); Maher v. Roe, 432 U.S. 464 (1977).

108. See Harris, 448 U.S. at 317 n. 19 (explaining that the withdrawal of "all Medicaid benefits" or "public benefits" from women who chose to have abortions would be an unconstitutional penalty). 
would courts aggregate and offset the benefit and harm in the first case but not in the second two? The distinction between withdrawal of a subsidy and imposition of a penalty seems to turn on an intuitive assessment of the connection between the government benefit that is being offered and the constitutional entitlement that must be surrendered in exchange. ${ }^{109}$ If the subject matter (and perhaps timing) of the benefit is closely connected to the constitutional right, as it seems to be in the Medicaid funding case, then the benefit will be regarded as part of the same government "program" (read, "transaction"). For a participant in that program, the cost of foregoing the constitutional entitlement will be outweighed by the value of the benefit. That is, the cost and benefit are effectively aggregated into a single net programmatic benefit. (We can be fairly sure that the benefit outweighs the cost in a given case because participation in the program is voluntary.) On the other hand, if the subject matter of the benefit is intuitively unrelated to the constitutional right, as it seems to be in the driver's license case, then it will be regarded as a different and independent program. Courts will not aggregate costs and benefits across programsthat is, across time and scope. Instead, they will evaluate the cost of foregoing the constitutional entitlement as a discrete unconstitutional transaction (and the benefit as a discrete discretionary gift for which the government has no restitutionary claim).

Sometimes, as in the abortion funding cases, this aggregation analysis is implicit in the distinction between penalties and failures to subsidize. In other unconstitutional conditions cases, however, the analysis is made explicit in the form of a nexus or germaneness requirement. For example, the Court has required that constitutionally problematic conditions on federal grants to state governments be "related" to the purposes of the federal spending program. ${ }^{110}$ Congress was permitted to cut federal highway funds to states that did not set a drinking age of at least twenty-one, the Court explained, because the drinking age condition "is directly related to one of the main purposes for which highway funds are expended-safe interstate travel." ${ }^{111}$ Had Congress threatened to cut crop subsidies instead, the Court probably would have balked. Similarly, in a series of takings cases, the Court has held that exactions from property owners as conditions for government grants of development permits are permissible only if the purpose of the exaction has an "essential nexus" to the purpose that would

109. This "germaneness" idea was first put forward as a descriptive theory of unconstitutional conditions cases by Robert Hale. See Robert L. Hale, Unconstitutional Conditions and Constitutional Rights, 35 COLUM. L. REV. 321 , 350-52 (1935); see also Kathleen M. Sullivan, Unconstitutional Conditions, 102 HARV. L. REV. 1415, 1456-76 (1989) (updating Hale's description of the significance of germaneness in unconstitutional conditions cases).

110. South Dakota v. Dole, 483 U.S. 203 (1987).

111. Id. at 208 . 
be served by prohibiting the proposed development altogether. ${ }^{112}$ Regardless of the vocabulary, the decisions in all of these cases turn on courts' willingness to aggregate the costs of foregone constitutional entitlements with the benefits bestowed by government in exchange. When the constitutional harm seems to be related to the discretionary benefit in some intuitive way, courts are willing to join them in the same transactional frame. When they seem unrelated, courts focus on the harm independently and see an unconstitutional condition.

We should pause to admire the delicacy of this framing exercise. In Nollan v. California Coastal Commission, the California state government conditioned the issuance of a development permit to beachfront property owners on the grant of an easement allowing the public to walk across their private beach. ${ }^{113}$ The justification offered by the government for denying the development permit was protection of the ocean view from the street. According to the Court, conditioning the permit on the public access easement was unconstitutional because the purpose of the easementallowing the public to traverse the private beach-would not affect the public's ability to see the beach from the street and therefore lacked the requisite nexus to the government's regulation of development. In a case like Nollan, then, the "nexus" requirement stands for the unwillingness of the Court to aggregate over scope. If the government had conditioned the development permit on exaction of a public "viewing spot," the Court would have been willing to aggregate the benefit of the permit together with the cost of the exaction and tally up a net gain for the property owners. ${ }^{114}$ But because public walking across the private beach was not sufficiently related in purpose to public viewing of the beach, the Court refused to aggregate the benefit of the permit and, evaluating the easement in isolation, treated it as an uncompensated taking. The slightest tightening of the transactional frame-refusing to aggregate a regulatory benefit that is contemporaneous with the exaction condition and connected to the same parcel of land-turns constitutionally permissible regulation into a taking by unconstitutional condition.

Nollan thus stands in remarkable contrast to the willingness of even the stingiest courts and commentators to offset benefits in takings cases. ${ }^{115}$ Even confined to individual-level reciprocity on the original Mahon model, and even respecting Professor Epstein's prohibition on aggregating across different statutes or programs, straightforward application of the reciprocity-of-advantage principle in a case like Nollan should allow offset

112. See Dolan v. City of Tigard, 512 U.S. 374, 386 (1994); Nollan v. Cal. Coastal Comm'n, 483 U.S. 825,837 (1987).

113. 483 U.S. 825.

114. See id. at 836-37.

115. See supra Section III.A. 
of the regulatory benefit to defeat takings liability. Only by fastidiously segregating costs and benefits in these cases can courts frame transactions in which the landowner is harmed by government. ${ }^{116}$

To appreciate the fragility of the Nollan Court's disaggregation of the exaction from the regulatory benefit, consider a clever strategy California might attempt in order to fuse them back together. Suppose that instead of conditioning the development permit on the public easement, the state simply used its eminent domain power to take the easement and offered just compensation in the form of the development permit. ${ }^{17}$ By tying the regulatory benefit to the exaction cost in a right-remedy relationship, the state would make it more difficult to keep the benefit outside the transactional frame and evaluate the cost in isolation. Not that there is any good reason why the very same benefit should "count" if it is formally offered as just compensation for an acknowledged taking rather than to offset the exaction in order to avoid a taking in the first place. ${ }^{118}$ Indeed, if this strategy were successful, we might wonder what other benefits, besides the development permit, the state could offer up as just compensation-for example, the coastal highway the state built without which the property owners would have no access to their slice of beach, or the state erosion control program that keeps the ocean out of the owners' living room. Here again, the position of the transactional frame, while constitutionally dispositive, seems perfectly arbitrary.

It is no wonder, then, that unconstitutional conditions cases seem so mysterious. Courts either ignore the problem of transactional framing altogether or try to solve it with nexus and germaneness requirements without bothering ever to explain why nearby government benefits should count but not benefits that happen to be just slightly further away. Notice that the range within which transactional frames expand and contract in these cases is much smaller than in regulatory takings cases, where a much broader set of government benefits may be invoked to offset regulatory losses. This simply reflects the structure of unconstitutional conditions doctrine, where, analytically, a highly salient government benefit is always immediately at hand - the very benefit to which the condition is attached. The issue in these cases is always whether the benefit and the condition should be aggregated into a single, smaller benefit or whether, instead, they should be separated into an unconstitutional harm and a free-floating, constitutionally irrelevant benefit. This is precisely the same transactional

116. The same is true of commentators. See RICHARD A. EPSTEIN, BARGAINING WITH THE STATE 187-91 (1993) (defending the result in Nollan).

117. See Douglas T. Kendall \& James E. Ryan, "Paying" for the Change: Using Eminent Domain To Secure Exactions and Sidestep Nollan and Dolan, 81 VA. L. REV. 1801 (1995).

118. See generally Daryl J. Levinson, Rights Essentialism and Remedial Equilibration, 99 COLUM. L. REV. 857 (1999) (blurring distinctions between rights and remedies in constitutional law). 
framing problem that arises in takings and many other types of constitutional cases. Unfortunately, its infamously inadequate accommodation in unconstitutional conditions cases is scarcely improved upon elsewhere.

\section{Economic Due Process and Rationality Review}

Compared to the small measure of aggregation that distinguishes unconstitutional conditions from innocuous conditional benefits, the transition from Lochner-era economic due process to modern rationality review might be understood to reflect aggregation on the grandest of scales. The difference between the Supreme Court's approach to economic regulation before and after $1937^{119}$ can be interpreted as the difference between, on the one hand, framing particular instances of wealth redistribution as constitutionally cognizable transactions and, on the other, implicitly aggregating and offsetting many instances of wealth redistribution over time into a holistic system of pluralist politics.

From the turn of the twentieth century through the mid-1930s, the Supreme Court struck down hundreds of economic regulations-maximum hour and minimum wage laws, labor laws, price regulations, and restrictions on business entry-that attempted to redistribute wealth and entitlements without a sufficiently "public" justification. States were permitted to engage in such redistribution through the exercise of their public-regarding police powers for the purpose of protecting the health or safety of the general public or some especially vulnerable group. ${ }^{120}$ They were not, however, permitted to interfere with market processes and outcomes just for the purpose of economically advantaging some individual or group at the expense of another. ${ }^{121}$ The Court's conception of economic due process prohibited this kind of "special" or "private interest" legislation, which furthered no "public" purpose but merely paid rents to some interest group that had successfully captured the political process at the expense of other interest groups or dispersed majorities. ${ }^{122}$ On this (caricatured) understanding, economic due process represented a

119. This date is shorthand for the end of the so-called Lochner era and the Court's switch-intime. As recent historical scholarship has demonstrated, however, it is probably a mistake to see an abrupt switch in the Court's approach to economic regulation and federalism issues in response to political pressure in 1937. See BARRY CUSHMAN, RETHINKING THE NEW DEAL COURT (1998).

120. See id; SUNSTEIN, supra note 106, at 40-67.

121. In Lochner v. New York, 198 U.S. 45 (1905), for example, the state might have been permitted to regulate the working hours of bakers to protect their, or the public's, health and safety. But the state was not permitted to regulate for the purpose of redistributing bargaining power from employers to bakers simply because the bakers' union had won a political victory in the legislature. (1984).

122. Cass R. Sunstein, Naked Preferences and the Constitution, 84 COLUM. L. REv. 1689 
Madisonian effort to prevent politically efficacious factions from commandeering the legislature to redistribute wealth and entitlements for no greater good than enriching themselves at others' expense. This, at any rate, is the understanding that Justice Holmes's famous dissent in Lochner attacked. Holmes argued that the Court's concern with protecting market allocations ought to be redirected to the political market, where interest groups should be permitted to compete freely for political benefits. ${ }^{123}$

Against this jurisprudential background, the post-New Deal Court's reconceptualization of the role of judicial review might be described as reconciling the Holmesian conception of free-market politics with the Madisonian concern about political exploitation. The Court's post-Lochner reconstruction of the role of judicial review, sketched in Carolene Products footnote four, ${ }^{124}$ reserves special judicial solicitude for those few groups, such as racial and religious minorities, that are systematically disadvantaged by some failure in the political market and likely to get less than their "fair share" of favorable outcomes. ${ }^{125}$ With respect to nondisadvantaged groups, on the other hand, the Court assumes that "those political processes... ordinarily relied upon to protect minorities" will suffice to ensure rough fairness of political outcomes over the long run without any need for judicial involvement. ${ }^{126}$ As long as a group can compete on roughly fair terms in the pluralist political marketplace, courts will not second-guess its political victories or defeats. One doctrinal consequence of this post-Lochner paradigm shift is modern rationality review. Since the New Deal, courts consistently have rejected due process and equal protection challenges to statutes and regulations that effect wealth transfers to and from nonsuspect classes, even when the statute or regulation quite obviously serves no more "public" a purpose than paying off a politically successful interest group. ${ }^{127}$

Within the realm of economic regulation affecting nondisadvantaged groups, then, we might think of the transition from Lochner to Carolene Products as a huge expansion in the transactional frame used to evaluate economic regulation. Instead of framing and assessing particular instances of wealth redistribution one at a time, the post-New Deal Court has implicitly aggregated the economic benefits and burdens of pluralist politics over time and scope into a single, unified transaction amounting to the pluralist political process as a whole. Interest groups will win some political

123. Lochner, 198 U.S. at $74-76$.

124. United States v. Carolene Prods. Co., 304 U.S. 144, 152 n.4 (1938).

125. See John HART ELY, DemOCRACY AND DiSTRUST (1980); Bruce A. Ackerman, Beyond Carolene Products, 98 HARV. L. REV. 713 (1985).

126. Carolene Prods., 304 U.S. at 152 n.4.

127. See, e.g., Minnesota v. Clover Leaf Creamery, 449 U.S. 456 (1981); U.S. R.R. Ret. Bd. v. Fritz, 449 U.S. 166 (1980); Ferguson v. Skrupa, 372 U.S. 726 (1963); Williamson v. Lee Optical, 348 U.S. 483 (1955). 
battles and lose others, the argument might go, but as long as they suffer no systematic disadvantage in the political process, courts can safely presume that economic benefits and burdens will come out roughly even in the long run. Thus, even a court adamantly opposed to horizontal redistribution of wealth to interest groups might not feel the need to intervene when, for instance, employers or landlords lose local political battles over minimum wages or rent control. Instead, putting a slightly more optimistic spin on Holmesian pluralism, the court might expect that, aggregating over time and scope, these landlords and employers will win their fair share of benefits through the political process. ${ }^{128}$

Indeed, a court truly enamored of pluralist politics might think it counterproductive to attempt to police the "rationality" of narrowly framed government acts, for any such attempt would miss the point of political bargaining and logrolling. A given statute or regulation might look like pure rent-seeking, divorced from any legitimate policy goal, when considered in isolation, but become perfectly comprehensible and justifiable when recognized as the political compensation paid to some constituency or interest group in exchange for support on a different statute or regulation. ${ }^{129}$ Vote trading across multiple statutes and regulations over time may contribute to maximizing preference satisfaction by taking account of intensities of preference. ${ }^{130}$ Against the background of complex and pervasive political exchange, then, a court concerned about whether some group was being denied its fair share of political benefits would have to maintain an expansive ledger of gains and losses over scope and time. Deferential post-New Deal rationality review may simply stand for courts' realization that the relevant transaction for analyzing redistributive exploitation through the political process is much larger than any particular statute or regulation.

128. What counts as a "fair share," of course, depends on some normative theory of a wellfunctioning political process or a distributively just outcome. See Einer R. Elhauge, Does Interest Group Theory Justify More Intrusive Judicial Review?, 101 YALE L.J. 31, 48-66 (1991). For present purposes, the point is simply that, consistent with a range of plausible such theories, courts might choose to assess redistributions wholesale rather than retail.

129. See Frank I. Michelman, Politics and Values or What's Really Wrong with Rationality Review?, 13 CREIGHTON L. REV. 487, 499-500 (1979).

130. On the basic theory of logrolling, see, for instance, JAMES M. BuCHANAN \& GORDON TULLOCK, THE CALCULUS OF CONSENT 131-45 (1965). Note that logrolling is not guaranteed to maximize preference satisfaction against the backdrop of majority-rule voting. Logrolling will tend to increase the utility of members of majority coalitions, but it will also enhance the ability of these coalitions to externalize (potentially greater) costs on minorities. For an explanation with examples, see DenNis C. MUELLER, PUBlic ChOICE 82-86 (2d ed. 1989). 


\section{Equal Protection and Race Discrimination}

The development of modern race equal protection jurisprudence traces a shrinking transactional frame that has left vanishingly little room for government allocation of benefits or burdens on the basis of race. In its recent affirmative action decisions, for example, the Court has been willing to permit government to distribute benefits on the basis of race, if at all, only to the extent necessary to compensate for the burdens of past discrimination. ${ }^{131}$ Only by offsetting all racially assigned benefits against past racially assigned burdens in a single transactional frame can government actors maintain the requisite racial "neutrality." How much affirmative action is permissible thus depends upon how many and what kinds of past racial burdens can be included in the frame. If government were allowed to aggregate all of its past racially discriminatory burdens, it would have practically unlimited latitude to engage in affirmative action to offset these burdens. ${ }^{132}$

The Supreme Court has preempted this permissive approach to affirmative action by limiting aggregation of past discrimination in a number of ways. It has held, for instance, that only racial harms that can be traced to specific, well-documented acts of past discrimination can be remedied by affirmative action benefits. ${ }^{133}$ Placing a high burden of proof on plaintiffs to demonstrate the causal link between past discrimination and present disadvantage effectively restricts aggregation over time. ${ }^{134}$ The Court has also limited specific government units or institutions to remedying only those racial harms resulting from their own discrimination (or, perhaps, from private discrimination within their jurisdiction). ${ }^{135}$ This

131. See Adarand Constructors, Inc. v. Pena, 515 U.S. 200 (1995); City of Richmond v. J.A. Croson Co., 488 U.S. 469 (1989).

132. This is the point of the liberal argument that affirmative action should be permitted to remedy general "societal discrimination." See Regents of the Univ. of Cal. v. Bakke, 438 U.S. 265, 362 (1978) (Brennan, J., concurring in part and dissenting in part) (arguing that racial preferences may be justified to remedy societal discrimination). But see Wygant v. Jackson Bd. of Educ., 476 U.S. 267, 274 (1986) ("[S]ocietal discrimination alone is [not] sufficient to justify a racial classification."); Bakke, 438 U.S. at 307 (opinion of Powell, J.) (calling societal discrimination "an amorphous concept of injury that may be ageless in its reach into the past" and rejecting it as the basis for a remedial rationale).

133. Croson, 488 U.S. at $498-506$.

134. Just to give one example, it is plausible to think that the institution of slavery has some causal relationship with persisting racial inequality, but empirical proof of such intergenerational effects to the satisfaction of a court would probably be impossible.

135. See Croson, 488 U.S. at 490-92; Wygant, 476 U.S. at 274 ("[T]he Court has insisted upon some showing of prior discrimination by the governmental unit involved before allowing limited use of racial classifications in order to remedy such discrimination."); see also Croson, 488 U.S. at 492 (explaining that a city that was a "passive participant" in private discrimination could take steps to remedy that discrimination); Ian Ayres \& Fredrick E. Vars, When Does Private Discrimination Justify Public Affirmative Action?, 98 CoLuM. L. REv. 1577 (1998) (suggesting three ways in which Croson's "passive participant" exception permits government entities to remedy certain private discrimination). 
prohibition on aggregation over scope prevents a state law school, for example, from defending racial preferences in admissions as a way of remedying past discrimination by the broader system of public schools in the state. ${ }^{136}$ Notice that these two restrictions on aggregation play essentially the same role as nexus, germaneness, and similar limitations on the expansion of transactional frames in takings and unconstitutional conditions cases, but reversing benefits and burdens: In the affirmative action context, the Court is concerned with preventing limitations on racebased affirmative action from drowning in a sea of offsetting race-based burdens.

At the same time, the Court has increasingly reined in aggregation over groups. Meaningful affirmative action programs are impossible if racebased benefits must be compensatory for race-based harms at the level of the individual. Individuals who have suffered race discrimination can always demand a judicial remedy. What distinguishes affirmative action programs implemented by nonjudicial government entities is the distribution of benefits to members of racial groups without individualized accounting, meaning that the beneficiaries are often different individuals from the victims of past discrimination. ${ }^{137}$ The constitutionality of remedial affirmative action thus depends on the Court's willingness to engage in group aggregation by assessing race-neutral treatment at the level of the group as a whole, irrespective of the distribution of benefits and burdens among members of that group. Not surprisingly, in opinions striking down affirmative action programs, the Court has come close to insisting that the beneficiaries be the very same individuals who were victimized by past discrimination, not merely different individuals of the same race (whether ancestors or contemporaries of the beneficiaries). ${ }^{138}$

The same pattern of limiting remedies by disaggregating past discrimination has structured the Court's approach to school desegregation. As in the affirmative action context, remedial desegregation is mandated (and permitted) only insofar as it offsets the effects of past discrimination and thus, in theory, restores the world to some approximation of what it would have looked like had government always behaved race-neutrally. Given that right and remedy must sum to zero, how much desegregation is permitted on the remedy side depends on how much unconstitutional race discrimination is taken into account as part of the constitutional violation. The more past government discrimination courts are willing to bring inside

136. Hopwood v. Texas, 78 F.3d 932, 950-52 (5th Cir. 1996); Grutter v. Bollinger, 137 F. Supp. 2d 821,869 (E.D. Mich. 2001).

137. See Croson, 488 U.S. at 520-28 (Scalia, J., concurring in the judgment).

138. See, e.g., id. at 526-27 (distinguishing permissible individual-level remediation for past discrimination from the use of race as a proxy for past discrimination by affirmative action programs). 
the transactional frame, the more offsetting, remedial desegregation will be warranted. Because past de jure discrimination contributing to segregated housing patterns and, consequently, public schools is in abundant supply, ${ }^{139}$ courts have had vast discretion to decide how much remedial desegregation to permit or require. Their answer has been less and less over time. ${ }^{140}$

In Swann v. Charlotte-Mecklenburg Board of Education ${ }^{141}$ and other early desegregation cases, ${ }^{142}$ a Court willing to experiment with aggressive school desegregation through busing and other measures was sympathetic to the arguments of civil rights lawyers that past discrimination by government at all levels, in many different forms, was largely responsible for existing segregation. ${ }^{143}$ This expansive view of relevant past discrimination supported an affirmative remedial obligation for school districts to achieve as much actual integration as possible. In the decades after Swann, however, the Court has been careful to limit the scope of the equal protection violation in school cases to discriminatory acts committed by local school boards alone; race discrimination on the part of other government entities has been categorically excluded. ${ }^{144}$ While the Court has been willing to adjudicate and remedy some forms of this discrimination in separate suits, ${ }^{145}$ much historical race discrimination affecting present-day segregation has simply disappeared from the desegregation frame. This has left little room for offsetting remedial desegregation. The rise and demise of constitutional school desegregation has thus been accomplished by aggregating and disaggregating past discrimination over time and scope.

139. For instance, metropolitan housing authorities, the Federal Housing Administration, and the Veteran's Administration implemented blatantly discriminatory housing policies in the years before Brown. Zoning and road building decisions and the enforcement of racially restrictive covenants also contributed to the growth of predominantly white suburbs and increasing residential segregation. In a broader sense, government surely bears some responsibility for racecorrelated wealth disparitics and even the racial attitudes of citizens, which in turn have contributed to residential and school segregation. See J. HARVIE WILKINSON III, FROM BROWN TO BAKKE: THE SUPREME COURT AND SCHOOL INTEGRATION: 1954-1978, at 140-45 (1979).

140. For overviews of the path of desegregation law, see JOHN C. JEFFRIES, JR., JUSTICE LEWIS F. POWELL, JR. 282-331 (2001); WILKINSON, supra note 139; Owen M. Fiss, School Desegregation: The Uncertain Path of the Law, 4 PHIL. \& PUB. AFF. 3 (1974); William A. Fletcher, The Discretionary Constitution: Institutional Remedies and Judicial Legitimacy, 91 YALE L.J. 635, 673-83 (1982).

141. 402 U.S. 1 (1971).

142. E.g., Keyes v. Sch. Dist. No. 1,413 U.S. 189 (1973).

143. See JEFFRIES, supra note 140, at 300-01; Levinson, supra note 118, at 874-78.

144. E.g., Missouri v. Jenkins, 515 U.S. 70, 102 (1995) (reversing a desegregation order requiring a school district to raise teacher salaries and build a lavishly appointed magnet school because this "quality education" program was not "tailored to remedy the injuries suffered by the victims of prior de jure [school] segregation"); Milliken v. Bradley, 418 U.S. 717, 744-45 (1974) (deciding that white students living in suburban school districts innocent of de jure segregation cannot be included in busing plans to desegregate urban schools).

145. E.g., Hills v. Gautreaux, 425 U.S. 284 (1976) (approving a metropolitan-area plan to remedy racial segregation in public housing operated by the Chicago Housing Authority). 
The constitutional status of separate-but-equal laws also has tracked shrinking transactional frames. One common understanding of the equal protection right is that it prohibits government from intentionally harming racial minorities, where "harm" is measured relative to government's treatment of similarly situated whites. A black plaintiff who raises an equal protection challenge to a school segregation ${ }^{146}$ or antimiscegenation law ${ }^{147}$ can plausibly argue that the law harms him compared to a hypothetical white person in his position because he, but not the white person, is prohibited from attending an all-white school or marrying a white partner. Yet the slightest broadening of the transactional frame will defeat this claim: Taking into account the corresponding disadvantage imposed by the very same law on a white man who wishes to attend an all-black school or marry a black woman will restore the appearance of government neutrality in its treatment of blacks and whites. ${ }^{148}$ Should courts broaden the transactional frame beyond race-based harm to the individual black plaintiff to encompass, and offset, congruent race-based harm stemming from the same law or policy to a similarly situated white person $?^{149}$ Nothing in a harm-based definition of the equal protection right determines whether this form of group aggregation is appropriate.

One should object at this point that the harms to blacks and whites from such laws are never really comparable. In light of social meaning and stigmatic harm, antimiscegenation and school segregation laws arising out of the Jim Crow South have no realistic claim to racial symmetry. Other separate-but-equal laws, however, might reasonably be understood to impose equivalent disadvantages on blacks and whites and thus present the possibility of aggregating and offsetting symmetrical harms. For example, in Palmore v. Sidoti, the Court unanimously disapproved the practice of basing child custody decisions on race. ${ }^{150}$ Similarly, in Batson v. Kentucky, the Supreme Court held that race-based peremptory strikes of jurors by

146. See Brown v. Bd. of Educ., 347 U.S. 483, 495 (1954).

147. See Loving v. Virginia, 388 U.S. 1 (1967) (striking down a state law prohibiting interracial marriage).

148. E.g., Pace v. Alabama, 106 U.S. 583 (1882) (upholding a state law criminalizing interracial sex and marriage against an equal protection challenge based on its symmetrical application to the black person and the white person who jointly violate the law).

149. Put another way, the issue seems to turn on whether the unit of analysis is the general rule or policy under which the govemment or employer is operating (" no interracial marriage") or whether, instead, it is the application of that rule or policy to an individual interaction ("you cannot marry a white person because you are black"). Cf. Matthew D. Adler, Rights Against Rules: The Moral Structure of American Constitutional Law, 97 MICH. L. REV. 1, 8 (1998) (arguing that constitutional rights are "rights against rules," and not "shields around actions"); John Harrison, Equality, Race Discrimination, and the Fourteenth Amendment, 13 CoNST. COMMENT. 243, 253-54 (1996) (recognizing the argument that "the right to marry a person of your own race makes up for the inability to marry a person of another race," but arguing that "[t]hat way of thinking is appropriate to universal equality, not nondiscrimination").

150. 466 U.S. 429 (1984). 
prosecutors in criminal cases violate equal protection. ${ }^{151}$ In both of these cases, the Court could have reasonably concluded that the laws and practices at issue inflicted comparable and offsetting harms on blacks and whites as groups. ${ }^{152}$ Despite the occasional push by some Justices for broader transactional frames of this sort, however, the post-Brown Court has steadfastly refused to aggregate harms beyond the individual plaintiff in these cases. The dissenters in Batson, for example, saw no tension between race-based peremptory challenges and racial equality, arguing that "there is simply nothing 'unequal' about the State's using its peremptory challenges to strike blacks from the jury in cases involving black defendants, so long as such challenges are also used to exclude whites in cases involving white defendants." ${ }^{153}$ The argument between the majority and the dissent in Batson is about whether race-based harm should be calculated at the level of each individual juror (or defendant ${ }^{154}$ ) or whether, instead, race-based harms should be aggregated over the group of black jurors, over the group of white jurors, and then offset. ${ }^{155}$

In theory, equal protection law might encounter many similar possibilities for expanding transactional frames to transform instances of race discrimination into more broadly equal treatment of blacks and whites. Imagine that a city police department institutes a policy of aggressive searches and arrests in a predominantly black neighborhood. The harm suffered by a neighborhood resident who is searched and arrested because of his race would, when viewed in isolation, amount to a clear-cut equal protection violation. But suppose the police documented a substantial reduction in crime in the neighborhood resulting from their efforts. In defending against equal protection challenges to their race-based searches and arrests, could the city offset the benefits of crime reduction conferred upon the neighborhood as a whole? To do so would require simultaneous aggregation over scope (the harms of police investigatory conduct and the

151. 476 U.S. 79 (1986); see also Georgia v. McCollum, 505 U.S. 42 (1992) (extending the Batson rule to peremptory challenges by criminal defense counsel).

152. This will not always be true in the Batson context. If there are many more whites than blacks on the venire, then permitting race-based peremptories will often allow prosecutors to eliminate all black jurors but seldom all white jurors. Insofar as the purpose of the Batson rule is to protect criminal defendants from racially antagonistic jurors, see infra note 154 , the result will not be equal treatment.

153. Batson, 476 U.S. at 137-38 (Rehnquist, J., dissenting).

154. Courts have been inconsistent in jury discrimination cases as to whether the constitutional harm has been suffered by the criminal defendant or the excluded juror. See Pamela S. Karlan, Race, Rights, and Remedies in Criminal Adjudication, 96 MicH. L. REv. 2001, 2015 (1998); Eric L. Muller, Solving the Batson Paradox: Harmless Error, Jury Representation, and the Sixth Amendment, 106 Y ALE L.J. 93, 118-19 (1996).

155. The same dispute could be played out in an individual trial, if the prosecutor and defense attorney both used peremptory challenges to exclude jurors on the basis of race, with the prosecutor typically excluding jurors of the same race as the defendant and the defense lawyer excluding jurors of a different race. 
benefits of crime reduction), time (short-term harms and longer-term benefits), and group (black victims of the police and perhaps different black beneficiaries of reduced crime) ${ }^{156}$ Cases like this already stretch the legal imagination, but it is important to recognize that the theoretical possibilities for aggregation and framing in the race context are limitless. If blacks as a group receive a disproportionate share of welfare benefits and pay lower taxes than whites as a group, does that mean that government can exclude blacks from public universities or charge them higher tuition? If antidiscrimination laws primarily benefit racial minorities, can government justify some measure of its own discrimination against racial minorities on the theory that the benefits of protection against private discrimination should be offset against the resulting harms? All of these attempts at aggregation over time, scope, and group would clearly fail as a matter of current equal protection law. But it is difficult to explain why arguments of this sort are not persuasive within a framework of transactional harm.

Finally, the discussion of race equal protection thus far has assumed, as the Supreme Court has held, that race discrimination requires a raceconscious motive or purpose and that racially disparate effects alone do not raise equal protection concerns. ${ }^{157}$ Notice, though, that temporal aggregation of harms could undermine the discriminatory purpose requirement as it is routinely applied. In many of the cases where courts disregard racially disparate effects because these effects are not seen as linked to racially discriminatory purposes, the requisite linkage could easily be established by aggregating backward in time. Take Washington v. Davis, in which the Court upheld a verbal skills test administered to applicants to the D.C. police department that blacks disproportionately failed. ${ }^{158}$ The Davis Court found no discriminatory purpose because it believed that the police department's motivation in administering the test was literacy and not race. But why focus solely on the purpose behind the test? The test's disproportionate impact on black applicants must have been in part a product of the intentionally segregated and unequal schools in the District. ${ }^{159}$ By enlarging the relevant transaction to include de jure school segregation along with the verbal skills test, the Court could have linked the racially discriminatory purpose to the causally connected, racially disparate effect and thus created an equal protection violation. Instead, the Court

156. See Randall Kennedy, The State, Criminal Law, and Racial Discrimination: A Comment, 107 Harv. L. RFv. 1255, 1266-70 (1994); William J. Stuntz, Race, Class, and Drugs, 98 COLUM. L. REV. 1795, 1796 (1998) (suggesting that police policies that seem to discriminate against certain communities "may actually be a subsidy of those same communities, a redistribution of the services of the criminal justice system in their favor").

157. Washington v. Davis, 426 U.S. 229, 239 (1976).

158. Id. at 235 . 30.

159. See SEIDMAN \& TUSHNET, supra note 106, at 108; SUNSTEIN, supra note 106 , at 329 - 
chose to disaggregate past de jure discrimination from present de facto discrimination, leaving the latter irremediable. ${ }^{160}$

\section{E. Gender Equality and Abortion}

The most important difference between gender and race equal protection is that the notion of legitimate "real" or "natural" differences between men and women continues to have currency. ${ }^{161}$ Because government can make constitutionally permissible gender classifications based on these "real" differences, contentious issues of separate-but-equal arise more often in modern gender equal protection law than in race equal protection law. The resulting puzzles of aggregation and framing, however, are just the same.

While forbidding the exclusion of women from the Virginia Military Institute, for example, the Supreme Court suggested that, under different circumstances, gender-segregated but otherwise equal schools might be constitutionally permissible. ${ }^{162}$ Suppose that a state sets up an experimental program of sex-segregated public junior high schools with special curricula designed by educational experts to accommodate the (hypothetically) different learning styles of adolescent males and females. A court inclined to uphold these schools against an equal protection challenge would have to rely on intra- or inter-group aggregation. As the VMI case demonstrates, there is bound to be at least one female student who would prosper in the male school (and vice versa). Her exclusion would, if viewed in isolation,

160. Positivism suspended, we might recognize in passing that the discriminatory purpose requirement itself can be understood to reflect a controversial choice of transactional frames. Suppose that racially disparate effects, even if unintentional, counted as a constitutionally cognizable type of harm. Starting from this premise, the Court's decision to forgive unintentional racially disparate effects would require an oddly gerrymandered frame, one that encompassed offsetting harms and benefits to racial minorities going forward in time but that excluded harm going backward. Going forward, disregarding racially disparate effects might reflect the presumption that, as long as these effects are unintentional, they will be more or less randomly distributed, so that harms and benefits falling on a given racial group will tend to balance out over the long term. This is aggregation over time and scope on the model of rationality review and Keystone. A similar willingness to aggregate backward in time, however, would make a mockery of this analysis. Over the long period when government intentionally disadvantaged blacks with constitutional impunity, harms to this group far outweighed harms to whites. Only by arbitrarily limiting the ledger of harms to those inflicted after the constitutional ban on intentional race discrimination was seriously enforced can a plausible presumption of net neutrality be maintained.

161. See United States v. Virginia, 518 U.S. 515, 533 (1996) ("Supposed 'inherent differences' are no longer accepted as a ground for race or national origin classifications. ... 'Inherent differences' between men and women, we have come to appreciate, remain cause for celebration ...."); Katherine M. Franke, The Central Mistake of Sex Discrimination Law: The Disaggregation of Sex from Gender, 144 U. PA. L. REV. 1, 11 (1995) (discussing the Court's different treatment of natural differences in the gender context, as opposed to the race context).

162. See Virginia, 518 U.S. at 534 n.7; see also id. at 563 (Rehnquist, C.J., concurring in the judgment) (seemingly agreeing that separate-but-genuinely-equal educational facilities would comply with equal protection). 
constitute an intentional harm inflicted on account of gender. Only by aggregating and offsetting the benefits of sex-segregated schools to other females, or the congruent harms to idiosyncratic males excluded from the female school, could a court portray sex-segregated schools as genderneutral. Once such group-level aggregation maneuvers are considered fair game, though, we might wonder what other types of gender classifications would be permitted. Just within the sex-segregated schools context, private women's colleges, as a group, receive much greater total government funding than the few remaining private men's colleges. Is government therefore justified in enhancing the educational opportunities available to male students by, for example, channeling greater resources to the hypothetical male junior high school, or even reestablishing an all-male public college on the model of VMI? Or does it work the other way around, so that the many past and present harms suffered by women at the hands of government-ranging from denial of property, contract, and voting rights to, until very recently, exclusion from VMI-in fact justify offsetting advantages for women to restore gender neutrality? Once the transactional frame around government treatment of males and females begins to expand, there is no clear stopping point short of a global, historical comparison of government's gender-respecting actions.

This point is nicely illustrated by the argument that laws restricting abortion violate gender equal protection. ${ }^{163}$ Abortion restrictions, the argument goes, impose a burden on women-conscripting their bodies to save the life of another-that would never be imposed on men. The asymmetry of the burden is exemplified by situations in which men's bodies could be conscripted by law to save the lives of their children but are not, for example, when a bone marrow transplant or blood transfusion would be the difference between life and death. In this view, the fact that the government only imposes an affirmative obligation to donate one's body to save the life of another in situations where women are the only eligible donors proves that abortion restrictions are based on either a devaluation of women's autonomy or a stereotypical understanding of women's "natural" role as childbearers. ${ }^{164}$ Framing the relevant transaction around these particular medical procedures portrays unequal treatment based on gender. But certainly there are other, no less plausible ways of framing the transaction that would restore the appearance of genderneutrality. The frame might be broadened, for example, to include

163. See Planned Parenthood v. Casey, 505 U.S. 833, 928 (1992) (Blackmun, J., concurring in part and dissenting in part).

164. For variations on this argument, see, for instance, SUNSTEIN, supra note 106, at 270-85; TRIBE, supra note 7, at 1353-54; Donald H. Regan, Rewriting Roe v. Wade, 77 MICH. L. REv. 1569 (1979); and Judith Jarvis Thomson, A Defense of Abortion, 1 PHIL. \& PUB. AFF. 47 (1971). 
government's conscription of men for military service and combat duty, ${ }^{165}$ which also involves bodily sacrifice for the sake of third parties. Is government behaving gender-neutrally, in a separate-but-equal sense, if it imposes the burdens of abortion restrictions on women and the burdens of military combat on men? Courts' willingness to aggregate over scope, bringing together government harms to men and women in a single transactional frame, may determine whether we see antiabortion laws and the military draft as two independent equal protection violations or as a single, gender-neutral set of policies. More generally, in a society that treats men and women differently in innumerable respects (often by applying the same rules in contexts where men and women are differently situated), the extent to which we see gender-based harm will depend largely on how these inequalities are packaged.

\section{F. Free Speech}

The speech capacity of individuals or corporations is largely dependent upon their wealth, which in turn is largely dependent on a network of government subsidies and structures ranging from corporate law to government-supported property rights. When government incrementally reduces an individual's or corporation's speech capacity, it can always point to any number of benefits that contributed to that baseline level of capacity. Whether or not courts are willing to frame transactions more broadly in order to capture and offset these benefits will determine whether government is restricting free speech or instead, on balance, subsidizing it.

In First National Bank of Boston v. Bellotti, ${ }^{166}$ for example, the Court struck down a state law limiting corporate expenditures intended to influence the results of a referendum. It did so over a dissent arguing that the restrictions could be justified by the benefits of the corporate formperpetual life, limited shareholder liability, and the like. ${ }^{167}$ In the dissenting view, the state-provided benefit of the corporate form should offset the burden of the campaign finance limitations in a broader transactional frame. This view subsequently prevailed in Austin v. Michigan State Chamber of Commerce. ${ }^{168}$ In that case, the Court upheld a state law prohibiting corporations from using general treasury funds for independent expenditures in support of candidates in state elections, emphasizing "the unique state-conferred corporate structure that facilitates the amassing of

165. See Rostker v. Goldberg, 453 U.S. 57 (1981) (rejecting an equal protection challenge to the male-only military draft).

166. 435 U.S. 765 (1978).

167. See id. at 825-27 (Rehnquist, J., dissenting).

168. 494 U.S. 652 (1990). 
large treasuries." ${ }^{169}$ Depending on how benefits and burdens are aggregated over time and scope, restrictions on political speech can be framed as slight reductions in a still-substantial stream of government speech subsidies or as stand-alone instances of suppression.

Constitutional debates surrounding government regulation of broadcast and other media provide an analogous example. In Red Lion Broadcasting Co. v. FCC, the Supreme Court upheld the FCC's "fairness doctrine," which required broadcasters to devote attention to public issues and to offer fair coverage of opposing viewpoints. ${ }^{170}$ The Court's decision was based in large part on the scarcity of broadcast frequencies and the necessity of government licensing. Licensees had no constitutional entitlement to their property rights in frequencies; they were merely the fortunate beneficiaries of government largesse. Consequently, broadcasters had no constitutional basis for complaining about having to share access to their frequencies with various viewpoints and voices that would otherwise be shut out by the limited supply of frequency space. ${ }^{171}$ Contrast Miami Herald Publishing Co. v. Tornillo, in which the Court held that newspapers were exempt from access mandates designed to ensure that a broad range of viewpoints reached the public. ${ }^{172}$ The different results in Red Lion and Miami Herald are conventionally understood to reflect a constitutional distinction between broadcast and print media, with more government leeway to regulate the former. ${ }^{173}$

This distinction has been widely criticized, ${ }^{174}$ but for present purposes it is more interesting to focus on how it was created. The Court's justification for allowing government regulation of broadcast media relies on a strategic expansion of the free speech transactional frame. The relevant constitutional burden-government restriction of the speech of broadcasters-is aggregated with the offsetting speech subsidy of a broadcast license, resulting in net government neutrality toward speech. In Miami Herald, on the other hand, the Court refused to take a comparable aggregation step. Just as government confers property rights on

169. Id. at 660 .

170. 395 U.S. 367 (1969). In 1987, the FCC itself decided that the faimess doctrine violated the free speech rights of broadcasters and repealed it. See OWEN M. FISS, THE IRONY OF FREE SPEECH 58-69 (1996).

171. See Red Lion, 395 U.S. at 391 ("[T]he First Amendment confers no right on licensees to prevent others from broadcasting on 'their' frequencies and no right to an unconditional monopoly of a scarce resource which the Government has denied others the right to use.").

172. 418 U.S. 241 (1974).

173. See also FCC v. Pacifica Found., 438 U.S. 726 (1978) (upholding resurictions on "indecent," but not necessarily obscene, content in radio broadcasts).

174. See, e.g., R.H. Coase, The Federal Communications Commission, 2 J.L. \& ECON. 1, $7-$ 12 (1959); L.A. Powe, Jr., "Or of the [Broadcast] Press," 55 TEX. L. REV. 39 (1976). But see LEE C. BOLLINGER, IMAGES OF A FREE PRESS 109-10 (1991) (justifying the Court's differential treatment of broadcast and print media as a compromise between the values of broad access and minimal government intrusion). 
broadcasters in the form of licenses, government confers property rights on newspapers in the form of, for example, trespass laws, which serve the identical purpose of allowing a newspaper to publish some views but not others. ${ }^{175}$ The Court in Miami Herald could have followed the logic of Red Lion and characterized the government's access requirement as a partial exception to the property right it had generously bestowed upon the newspaper, rather than as a freestanding harm, separate from the gratuitous benefit of trespass law. ${ }^{176}$

Red Lion and Miami Herald represent opposing positions not just on the appropriate amount of aggregation of economic benefits over time and scope, but also on the permissibility of group aggregation in free speech jurisprudence. On one broad understanding of free speech, represented by Miami Herald, government is simply prohibited from interfering with private expression. The "negative liberty" of speakers in the private marketplace of ideas is the paramount First Amendment value. On a competing, and equally broad, understanding of free speech, however, government is obligated to play a much greater role in regulating the marketplace of ideas to amplify some voices and silence others. Achieving and maintaining some conception of robust public discourse is the paramount First Amendment value. This second, "civic republican" understanding has been an important countercurrent in First Amendment theory and has occasionally prevailed in judicial decisions. ${ }^{177}$ In Red Lion, for example, the Court emphasized the "right of the public to receive suitable access to social, political, esthetic, moral, and other ideas and experiences," instead of the asserted right of broadcasters to freedom from government interference in their programming. ${ }^{178}$

The tension between negative liberty and civic republican approaches to free speech structures many of the most interesting doctrinal and theoretical debates. Is government permitted to use campaign finance regulations to "restrict the speech of some elements of our society in order

175. Cass R. Sunstein, Democracy and the Problem of FreE SPEeCh 108-10 (1993).

176. Compare this discussion with the decision in Minneapolis Star \& Tribune Co. v. Minnesota Commissioner of Revenue, 460 U.S. 575 (1983), where the Court struck down a special use tax on paper and ink used to produce newspapers. The use tax substituted for the general sales tax, from which newspapers were exempt. No one disputed that the state would be free to subject newspapers to the general sales tax or that the special use tax cost newspapers less than the sales $\operatorname{tax}$ (because only the value of raw materials was taxed, not the final product). Yet the Court held that a "special tax that applies only to certain publications" violates the First Amendment freedom of the press. Id. at 581 . In effect, the Court refused to aggregate the special use tax with the exemption from the general sales tax.

177. See DANiel A. Farber, The First AmEndment 220-22 (1998) (using "civic republican" terminology); FISS, supra note 170, at 50-78 (1996); SUNSTEIN, supra note 175, at 48-51.

178. Red Lion Broad. Co. v. FCC, 395 U.S. 367, 390 (1969); see SUNSTEIN, supra note 175, at $48-50$. 
to enhance the relative voice of others?" ${ }^{179}$ Can government restrict pornography or hate speech that (arguably) "silences" the voices of disadvantaged groups in order to promote equal access to public debate? ${ }^{180}$ Can it selectively subsidize art? ${ }^{181}$ Each of these debates turns on whether the First Amendment allows government to restrict or subsidize the speech of some in order to create a more robust or diverse public discourse on the whole. In other words, the question is always whether government can aggregate over groups, offsetting the benefits of enhanced voice to the speakers and potential listeners of some subsidized viewpoint against the harms of diminished voice to the speakers and potential listeners of some burdened viewpoint. Taking the negative liberty approach, courts in these cases have tended to focus narrowly on the burden of government suppression of speech (or subsidization of a substitute viewpoint), assessing harm at the level of an individual speaker. The competing civic republican approach would instead assess government's effect on speech at the level of a broader group of speakers and listeners. Unfortunately, if all we know about the meaning of the First Amendment is that it prohibits the government from inflicting the transactional harm of "abridging" speech, we have no basis for choosing between these drastically different approaches to framing free speech cases.

\section{G. Religious Neutrality}

Sometimes the Establishment Clause of the First Amendment forbids government from providing financial or in-kind benefits to religious groups. For example, the Supreme Court has struck down a number of government programs providing aid to private religious schools and to families with children enrolled in these schools. ${ }^{182}$ It has also refused to allow state

179. Buckley v. Valeo, 424 U.S. 1, 48-49 (1976) (per curiam) (answering this question in the negative).

180. See R.A.V. v. St. Paul, 505 U.S. 377 (1992) (answering no in the context of hate speech); Am. Booksellers Ass'n v. Hudnut, 771 F.2d 323 (7th Cir. 1985), aff'd mem., 475 U.S. 1001 (1986) (answering no in the context of pomography).

181. See NEA v. Finley, 524 U.S. 569 (1998) (leaving the answer ambiguous).

182. See, e.g., Wolman v. Walter, 433 U.S. 229 (1977) (striking down government reimbursement of nonpublic schools for teacher salaries and textbooks); Lemon v. Kurtzman, 403 U.S. 602 (1971) (striking down government reimbursement of nonpublic schools for instructional materials and the costs of field trips); see also Meek v. Pittenger, 421 U.S. 349 (1975) (striking down a program of lending instructional materials, such as maps and laboratory equipment, to nonpublic schools); Sloan v. Lemon, 413 U.S. 825 (1973) (striking down tuition reimbursements offered only to parents of children in nonpublic schools); Comm. for Pub. Educ. \& Religious Liberty v. Nyquist, 413 U.S. 756 (1973) (striking down tax credits and deductions offered only to parents of children in nonpublic schools). Compare Aguilar v. Felton, 473 U.S. 402 (1985) (barring a city from sending public school teachers into parochial schools to provide education to disadvantaged children), with Agostini v. Felton, 521 U.S. 203 (1997) (overruling Aguilar and permitting public educators to provide remedial education to students in sectarian schools). But see Mitchell v. Helms, 530 U.S. 793 (2000) (upholding a government program providing 
governments to establish a separate school district for a village of Orthodox Jews or to exempt religious publications from sales taxes. ${ }^{183}$ In other cases, however, the Free Exercise or Free Speech Clauses are understood to require government to provide similar benefits to religious groups. In a series of free exercise cases, the Supreme Court has required government to provide exemptions from generally applicable laws that would burden religious beliefs or practices by, for instance, requiring Amish children to attend high school. ${ }^{184}$ The Court has also found First Amendment violations when public schools or universities make resources and facilities available to secular student groups but not religious ones. ${ }^{185}$ In both sets of casesthe ones forbidding government benefits and the ones requiring them-the Court purports to be giving effect to the First Amendment by holding government to an ideal of "neutrality" with respect to religion. ${ }^{186}$ The differing results turn on the degree to which the Court is inclined to aggregate benefits to religious groups together with comparable benefits to secular groups. In the parochial school cases, for example, by placing a

educational materials and equipment to public and private schools); Zobrest v. Catalina Foothills Sch. Dist., 509 U.S. 1 (1993) (upholding a school district's payment of the salary of a signlanguage interpreter for a deaf student attending a parochial high school); Witters v. Wash. Dep't of Servs. for the Blind, 474 U.S. 481 (1986) (upholding a statute authorizing payment to blind students for vocational rehabilitation services where the recipient wanted to use the funds to pay tuition at a Christian college to prepare himself for a career as a minister); Mueller v. Allen, 463 U.S. 388 (1983) (upholding a tax deduction for the costs of tuition, textbooks, and transportation for parents of children in both public and nonpublic schools); Bd. of Educ. v. Allen, 392 U.S. 236 (1968) (upholding government loans of textbooks to students in nonpublic schools); Everson v. Bd. of Educ., 330 U.S. 1 (1947) (upholding government reimbursement of parents of students in both public and nonpublic schools for the costs of bus transportation).

183. See Bd. of Educ. of Kiryas Joel Vill. Sch. Dist. v. Grumet, 512 U.S. 687 (1994); Tex. Monthly, Inc. v. Bullock, 489 U.S. 1 (1989).

184. See Wisconsin v. Yoder, 406 U.S. 205 (1972); see also Sherbert v. Verner, 374 U.S. 398 (1963) (holding that the denial of unemployment compensation to a Seventh-Day Adventist who would not work on Saturdays violated the Free Exercise Clause). But see Employment Div. v. Smith, 494 U.S. 872 (1990) (holding that free exercise does not require government to provide religious exemptions from religion-neutral, generally applicable laws).

185. See Good News Club v. Milford Cent. Sch., 121 S. Ct. 2093, 2104 (2001); Rosenberger v. Rector \& Visitors of Univ. of Va., 515 U.S. 819 (1995); Lamb's Chapel v. Ctr. Moriches Union Free Sch. Dist., 508 U.S. 384 (1993); Widmar v. Vincent, 454 U.S. 263 (1981).

186. On the centrality of the ideal of government "neutrality" to Religion Clause jurisprudence, see FREDERICK M. Gedicks, THE RHETORIC OF ChURCH AND STATE (1995); Douglas Laycock, Formal, Substantive, and Disaggregated Neutrality Toward Religion, 39 DePAul L. REV. 993 (1990); and Michael W. McConnell \& Richard A. Posner, An Economic Approach to Issues of Religious Freedom, 56 U. CHI. L. REV. I (1989).

While "neutrality" or "nonpreferentialism" is often the explicit concern of Religion Clause cases and theoretical debates, sometimes the focus shifts to "noncoercion." See, e.g., Lee v. Weisman, 505 U.S. 577,587 (1992) (invalidating prayers at high school graduation ceremonies largely because of the pressure on students to attend and participate; holding that "government may not coerce anyone to support or participate in religion or its exercise"). Despite the differences in vocabulary, there is considerable overlap between the neutrality and noncoercion analyses, inasmuch as coercion depends on how attractive government makes religion as compared to the relevant nonreligious substitute in a given context. Equal treatment of religion and nonreligion by government would seem to obviate both nonneutrality and coercion problems. 
constricted frame around the government assistance being provided, the Court has sometimes created a picture of special, nonneutral government aid to religion. Alternatively, by expanding the frame to include government-provided secular public schools, the Court has at other times portrayed assistance to parochial schools as merely a small step toward providing religious education with the level of benefits routinely appropriated to secular education. The results depend on the Court's willingness to engage in the intergroup aggregation and offset of religious and secular subsidies.

Expanding the transactional frame beyond the narrowly defined benefit government has conferred on some religious organization in these cases makes the results seem even more arbitrary. For example, a transactional frame broad enough to encompass the benefit of secular public education would seemingly permit government to transfer vast resources to religious groups in exchange. Indeed, in order to remain neutral in its treatment of religion and nonreligion once secular public schools are taken into account, government would seemingly be required to provide comparable support to religious schools through direct subsidies or voucher programs-or else to bring religion into public schools, putting faith-based instruction on a par with secular instruction wherever the two might be considered substitutes for one another. Of course, the Cuurt has never gone this far in the parochial school context. Instead, in cases upholding government aid to religious schools, the Court has aggregated just enough secular benefits to permit, but not require, the type of aid at issue. In allowing a state to grant tax deductions for parochial school tuition, for instance, the Court relied on the equal availability of tax deductions for nonreligious schools to conclude that government was being neutral as between religion and nonreligion. ${ }^{187}$ Had the Court stretched the frame a bit further to include tax-financed public schools generally, it would have been compelled to conclude that the tax deduction scheme did not go nearly far enough to avoid the free exercise violation of government favoritism of nonreligion.

This is precisely the strategy the Court has pursued in other contexts, dragging enough secular benefits into the transactional frame to render government's failure to provide some benefit to religion unconstitutional. For example, the University of Virginia was found to have violated the First Amendment by denying student activity fee funding to student-run religious publications while offering funding to secular publications. ${ }^{188}$ Viewed in a narrow frame, the university's failure to subsidize religious publications would appear neutral. Had the university voluntarily funded such publications, a narrow frame might even create an establishment violation.

187. See Witters, 474 U.S. at $487-88$.

188. Rosenberger, 515 U.S. at 837. 
By expanding the transactional frame to encompass university funding of a broad range of secular publications, however, the Court portrayed the university as singling out religious ones for disadvantageous treatment. Neutrality, in this frame, clearly requires funding religious and nonreligious publications on an equal basis. The only thing that is left unclear is why this frame is the right one.

\section{H. Separation of Powers and Federalism}

The discussion so far has addressed transactional framing problems in constitutional cases arising out of the relationship between government and private citizens. It is worth recognizing that analogous framing issues arise in "structural" constitutional cases involving relations among the branches of the federal government, among the states, and between the federal and state governments. In these cases as well, attempts to impose a model of transactional harm on repeat-play relationships results in inconsistent and easily manipulable transactional frames.

Many controversies related to the constitutional separation of powers reduce to disagreements about how to take account of the historical expansion of executive branch power corresponding to the rise of the administrative state. ${ }^{189}$ Since the New Deal and the demise of the nondelegation constraint, Congress has, without constitutional impediment, delegated tremendous amounts of policymaking authority to administrative agencies. ${ }^{190}$ From the perspective of separation of powers, a sensible response might be to permit compensating adjustments, like the legislative veto or congressional limitations on the President's removal power, that would shift some power back from the executive to Congress. ${ }^{191}$ Even if these adjustments might, when considered in isolation, violate formalistic separation of powers constraints, the argument goes, they are justified by their contribution to the ultimate, functional goal of the constitutional separation of powers, namely, balancing power between the executive and Congress. A competing reaction to the rise of the administrative state is simply to ignore it. So-called formalist commentators and judges may acknowledge the affront to separation of powers principles represented by the modern administrative state, but they hold present arrangements constant for the purpose of evaluating the constitutionality of further

189. Michael J. Klarman, Antifidelity, 70 S. CAL. L. REV. 381, 398-401 (1997).

190. See Martin S. Flaherty, The Most Dangerous Branch, 105 YALE L.J. 1725, 1819-21 (1996).

191. See id.; Abner S. Greene, Checks and Balances in an Era of Presidential Lawmaking, 61 U. CHI. L. REv. 123 (1994). 
incremental shifts of power between the branches. ${ }^{192}$ Formalists thus evaluate innovations like the legislative veto in isolation from the background distribution of power among the branches, ignoring any ameliorative effects these devices might have on the imbalance of power in favor of the executive. Once again, the disagreement between formalist courts and commentators, on the one hand, and those who would take account of compensating adjustments, on the other, turns on the appropriate transactional frame. The issue is whether we ought to aggregate over time and scope to bring the rise of administrative agencies and the corresponding aggrandizement of the executive into the same frame as the procedural innovation at issue, or whether we ought instead to assess the procedural innovation in a frame by itself.

Take the debate over the constitutionality of the legislative veto. In INS $v$. Chadha, the Court invalidated a legislative veto because it violated Article I, Section 7's formal requirements of bicameralism and presentment for legislative action. ${ }^{193}$ To the Justices in the majority, the legislative veto represented an end-run around two crucial procedural constraints on the "hydraulic pressure inherent within each of the separate Branches to exceed the outer limits of its power" 194 - that is, it represented a power grab by Congress at the expense of the executive branch. ${ }^{195}$ The majority focused its analysis quite narrowly on the bypass of these two procedures and the incremental increase in congressional power that would result if the legislative veto were permitted. Justice White's dissent, in contrast, contemplated a much broader transactional frame. In Justice White's view, the legislative veto merely allowed Congress to reserve a modicum of the vast policymaking authority it routinely delegates to the executive branch in statutes authorizing unstructured and unsupervised agency rulemaking. ${ }^{196}$ As the debate in Chadha demonstrates, whether the legislative veto is seen as a usurpation of power by Congress from the executive or, instead, as a slight diminution in the huge amount of power that Congress continues to relinquish to the executive depends on how broadly the transaction between the executive and legislative branches is framed.

Framing disputes also arise in a number of different federalism contexts. An especially transparent example is the issue of "compensatory" taxes under the dormant Commerce Clause. States are forbidden by the

192. Thomas W. Merrill, The Constitutional Principle of Separation of Powers, 1991 SuP. CT. REV. 225, 234.

193. 462 U.S. 919 (1983). By summarily affirming lower court decisions striking down different legislative vetoes in the wake of Chadha, the Court has strongly suggested that all legislative vetoes are constitutionally suspect. See Process Gas Consumers Group v. Consumer Energy Council of Am., 463 U.S. 1216 (1983); U.S. Senate v. FTC, 463 U.S. 1216 (1983).

194. Chadha, 462 U.S. at 951.

195. See Laurence H. Tribe, American Constitutional Law 142-43 (3d ed. 2000 ).

196. See Chadha, 462 U.S. at $984-87$ (White, J., dissenting). 
dormant Commerce Clause to impose discriminatory taxes that burden outof-state economic interests and benefit in-state economic interests. ${ }^{197}$ The question that often arises is whether a state can justify a tax that falls more heavily on out-of-staters by pointing to a formally separate, compensatory tax that imposes at least an equivalent burden on in-staters. In other words, can a state aggregate and offset two or more taxes within a broader transactional frame for purposes of dormant commerce analysis, or must each tax stand or fall as a separate transaction? The Court's answer seems to be that aggregation is permissible only where the compensating tax and the discriminatory tax are imposed on the same activity or event. Thus, the State of Washington was permitted to impose a two percent tax on goods purchased out-of-state and used within the state because this use tax compensated for Washington's two percent sales tax on goods purchased in-state. ${ }^{198}$ In contrast, Oregon was not permitted to impose a surcharge on out-of-state waste shipped into the state for disposal. ${ }^{199}$ Oregon argued that the surcharge compensated for the financial burden on in-staters from waste disposal, paid in the form of income taxes and other "general" taxation. ${ }^{200}$ The Court rejected this argument, and distinguished the Washington compensatory use tax case, on the ground that earning income and disposing of waste are not "substantially equivalent events." 201 One searches in vain, however, for some explanation of why this kind of subject-matter connection between the taxes should matter. If the overall tax burden on out-of-staters is no greater than the overall tax burden on instaters for a roughly equivalent benefit, then it is hard to understand how a state could be guilty of the kind of discrimination that the dormant Commerce Clause is designed to prevent. ${ }^{202}$

For that matter, it is far from clear why the dormant commerce analysis must be limited to the sphere of taxation. In response to a dormant commerce challenge to a particular tax or regulation, a state might point out offsetting economic benefits it has conferred upon out-of-staters in any number of different forms: high welfare payments that attract the poor from neighboring states, vast acres of landfill space made available for out-ofstate waste, quality schools that create human capital benefits that migrate out of the state, cultural or recreational amenities enjoyed by out-of-staters,

197. For a general discussion of the doctrine, see TRIBE, supra note 195, at 1107-32.

198. Henneford v. Silas Mason Co., 300 U.S. 577 (1937).

199. Or. Waste Sys. v. Dep't of Envtl. Quality, 511 U.S. 93 (1994).

200. Id. at 104 .

201. Id. at 104-05; see also Fulton Corp. v. Faulkner, 516 U.S. 325 (1996) (rejecting another compensatory tax defense because the offsetting taxes were not tied to substantially equivalent events).

202. Richard Epstein argues that compensating use taxes should virtually never be taken into account for the same reason that "step transactions" in takings should seldom be permitted: roughly, that the two taxes may not in fact offset one another. EPSTEIN, supra note 116, at 141-44 (1993). But see supra text accompanying note 98 (questioning the force of this rationale). 
or subsidies to in-state businesses that are passed on to out-of-state consumers. ${ }^{203}$ (And out-of-staters might respond with a comparable litany of externalized harms.) If the ultimate goal of dormant Commerce Clause doctrine is simply to ensure that a state treats out-of-state economic interests no worse than in-state interests, ${ }^{204}$ this invites the argument that the only relevant transaction is the total economic exchange between the instate and out-of-state interests. Needless to say, it would be impossible for a court to make the necessary calculations to determine the net benefits or costs of a state's economic interactions with out-of-staters over even a relatively short time period. There are severe practical limits on the amount of aggregation over scope and time that courts could ever hope to administer. ${ }^{205}$ The dilemma, however, is that the dormant commerce norm may provide no normative reason for caring about whether the arbitrary slivers of interstate interactions that are scrutinized by courts in actual dormant commerce cases happen to be discriminatory.

Similar framing puzzles arise in constitutional regimes governing the relationship between the federal government and the states. Consider the contentious political issue of federal unfunded mandates and the closely related constitutional prohibition on "commandeering." The Supreme Court recently has decided that it is unconstitutional for the federal government to "commandeer" state governments " "by directly compelling them to enact and enforce a federal regulatory program." 206 In Printz $v$. United States, for example, the Court struck down the Brady Act's interim conscription of local law enforcement officers to conduct background checks on prospective handgun purchasers. ${ }^{207}$ Perhaps significantly, the federal programs invalidated in these anticommandeering cases took the form of unfunded mandates, forcing state and local governments both to implement federal policies and to pay the costs. If these decisions are understood as forbidding only unfunded mandates but allowing funded ones, then they create an intergovernmental rule analogous to just compensation for takings. The federal government may require state governments to help administer its regulatory programs, but it must pay

203. A further question arises at this point as to whether the nondiscrimination rule should be applied bilaterally between two states or between the challenged state and all other states aggregated together into a single comparison group.

204. At least when a state is "regulating" as opposed to "participating" in the market. See, e.g., S.-Cent. Timber Dev. v. Wunnicke, 467 U.S. 82, 93 (1984) ("Our cases make clear that if a State is acting as a market participant, rather than as a market regulator, the dormant Commerce Clause places no limitation on its activities.").

205. This is the grain of truth in Epstein's arguments against step transactions and compensatory taxes. See supra note 202.

206. New York v. United States, 505 U.S. 144, 161 (1992) (quoting Hodel v. Va. Surface Mining \& Reclamation Ass'n, 452 U.S. 264, 288 (1981)).

207. 521 U.S. 898 (1997). 
compensation for their services. ${ }^{208}$ Described in these terms, the anticommandeering prohibition on unfunded mandates raises all the same questions as offsetting benefits and reciprocity of advantage in the ordinary government-citizen takings context. Can the federal government defeat a charge of commandeering by pointing to benefits it has conferred on state governments through different spending programs that add up to at least the cost of the mandate? If the constitutional problem really is unfunded mandates, it is hard to see why it should make any difference whether Congress bundles a grant and a mandate in the same statutory package or enacts them in separate statutes. Given that many state and local governments enjoy net federal subsidies, ${ }^{209}$ the aggregation of federal benefits over scope and time could turn many "unfunded" mandates into more-than-fully funded ones.

\section{Overview: Constitutional Law's Transactional Frame-Up}

We have seen over and over again that constitutional prohibitions against transactional harm are undermined by expanding transactional frames. Any question of harm to an individual's constitutionally protected interest can be translated, by expanding the frame and aggregating over time and scope, into the question of whether she is, or will end up, better or worse off with respect to that interest as a result of some larger slice of her relationship with government. At the limit, taking into account the effects of all government actions over an entire life, insuperable accounting difficulties give way to unfathomable questions of political theory: Is the individual better or worse off as a result of her entire course of dealings with government? Compared to what state of nature? While these questions always lie at the end of the track, any serious attempt to keep a ledger of costs and benefits will go off the rails at a much earlier stage of aggregation over time and scope.

The possibility of group aggregation adds a further layer of indeterminacy. Aggregating harms and benefits over groups switches the unit of constitutional analysis from the net welfare of an individual, to, at the limit, the net welfare of society as a whole. How the welfare of society

208. Admittedly, this may not tum out to be an accurate reflection of how the Court understands commandeering. The majority opinion in Printz suggests in passing that even federally funded mandates may qualify as unconstitutional commandeering. See id. at $914 \mathrm{n} .7$, 930. Nevertheless, the constitutional prohibition has grown up around unfunded mandates, and one suspects that the lack of funding has at least contributed to the Court's inclination to see a constitutional problem here.

209. See Daniel H. Cole \& Carol S. Comer, Rhetoric, Reality, and the Law of Unfunded Federal Mandates, 8 STAN. L. \& POL'Y REV. 103, 109-10 (1997) (observing that the total amount of federal money flowing to states and cities-in the form of block grants, categorical grants, and tax subsidies-substantially exceeds the amounts states and cities are forced to spend on federal mandates). 
under government compares to the welfare of society without government is, once again, a nice question of political theory. (Hobbesians might be prepared to conclude that because any government is vastly superior to no government, there is no meaningful sense in which real-life government can be held accountable for net harms.) But the problems inherent in group aggregation, as well, are readily apparent even in its more modest forms. Assessing and comparing the net effects of even an isolated government program - say, the military draft —on men and women as groups may be a dispositively daunting theoretical and practical challenge.

If transactional harm is the touchstone of constitutional liability, then unrestricted transactional frames threaten to undermine constitutional liability altogether. In a few settings, courts and commentators are content with this result: Regulatory takings and modern rationality review are good examples of judicial expansion of frames to free government from constitutional constraints almost altogether. In most areas of constitutional law, however, transactional frames are selectively circumscribed to preserve liability over some range of cases. The obvious problem then becomes how to decide which harms and benefits should be included within the transactional frame. Given that many benefits and harms will inevitably be excluded from consideration, we will always have reason to ask what is distinctive about those harms and benefits that make it into the transactional frame and why we should care about this particular partial accounting when the result of a fuller accounting might well be different.

When it comes to aggregation over time and scope, the answers to those questions usually take the form of a nexus or germaneness test. Only those government benefits that are relatively closely connected to the challenged constitutional harm in time, scope, or legislative packaging are included in the frame. Thus, in takings cases where courts are willing to recognize some forms of implicit compensation, the benefits taken into account ordinarily must stem from the same government project or program that is being challenged as a taking. Germaneness and nexus requirements reappear in unconstitutional conditions cases, on the surface or just below, to resolve when the government benefit and its attached condition merge into a single transaction and when, instead, they must be evaluated separately. The Court's current approach to affirmative action appeals to notions of nexus and germaneness in its insistence on specific proof of a remedial linkage between present benefits and specific acts of past discrimination, as well as in its unwillingness to form that linkage across the jurisdictional boundaries of particular government institutions. In school desegregation cases, the Court has appealed to similar intuitions to keep the de jure violations of school boards separate from other forms of intentional government discrimination that contributed to housing segregation. Applying a tacit germaneness criterion, gender equal protection 
jurisprudence views the exclusion of women from combat and abortion restrictions as raising two entirely separate issues of gender discrimination, rather than a single issue of separate-but-arguably-equal. In religion cases, likewise, courts sometimes frame government aid to private religious schools together with government aid to private nonreligious schools, and might eventually be persuaded to bring government support of secular public schools into the frame as well, but it is hard to imagine courts simultaneously comparing government's treatment of various religious and nonreligious groups across different contexts. (Do the U.S. Centers for Disease Control violate the Establishment Clause by not giving equal time to Christian Scientists, and, if so, can government restore religious neutrality by subsidizing the Christian Science Monitor or faith-based schools?) In the dormant commerce context, discriminatory taxes can only be offset against one another when they apply to the same activity or event. In each of these contexts, harms and benefits may be aggregated only to the extent that they are temporally, topically, or procedurally related in some intuitive way. ${ }^{210}$

Unfortunately, these limits are far easier to recognize than to explain. What, after all, is the germaneness of germaneness? Absent some explanation of why proximate harms and benefits are especially relevant to one another, nexus and germaneness limitations on aggregation over time and scope seem to be recommended by little more than the understanding that constitutional law is impossible if transactional frames may be expanded indefinitely. ${ }^{211}$

210. Of course everything is related to everything else under some subject-matter description or within some time frame. The meaningful questions are always which description and which time frame. Without some theory of why nexus or germaneness should matter at all, however, courts and commentators have no hope of justifying their answers to these questions within this vocabulary.

211. With respect to subject-matter germaneness, some benefits may be so different in a qualitative sense that we might be legitimately uncomfortable thinking of them as commensurable with the constitutionally relevant harm. See ELIZABETH ANDERSON, VALUE IN ETHICS AND ECONOMICS 44-64 (1993); Cass R. Sunstein, Incommensurability and Valuation in Law, 92 MICH. L. REV. 779 (1994). If the benefit and the harm cannot be compared on a single metric of value, there may be no meaningful sense in which the benefit "offsets" or "compensates" for the harm. See Margaret Jane Radin, Compensation and Commensurability, 43 DUKE L.J. 56 (1993). Similarly, a principle of complex equality in distribution, requiring that harms and benefits be evaluated in the context of particular areas of social and political life rather than globally, might suggest some complementary limits on aggregation. See MICHAEL WALZER, SPHERES OF JUSTICE (1983). Taken together, incommensurability and complex equality concerns might justify a refusal to aggregate the gender-specific conscriptions of men for combat duty and women for abortion, or the harms to African Americans stemming from slavery and affirmative action benefits like admissions preferences and construction set-asides in equal protection analysis.

With respect to temporal linkages, moreover, weak constraints on aggregation might be derived from certain philosophical views of personal identity over time. See generally THE MULTIPLE SElF: STUdiES IN RATIONALITY AND SOCIAL CHANGE (Jon Elster ed., 1986) (exploring implications of thinking about an individual person as a set of selves); DEREK PARFIT, REASONS AND PERSONS 199-347 (1984) (propounding a theory of personal identity that contemplates multiple selves over time). Just as we find age discrimination normatively 
As for group aggregation, nothing internal to a general model of constitutional rights as prohibitions on transactional harm dictates the choice between individual-level and group-level analysis. Nevertheless, the default assumption in most areas of constitutional law seems to be that harms and benefits must be calculated at the level of the individual. At the same time, however, group-level analyses often compete for attention and occasionally prevail. As we have seen, group aggregation plays a prominent role in regulatory takings cases, where the Court suggests that reciprocity of benefit at the level of some community, or society, is sufficient to avoid triggering the just compensation requirement. This is the same groupaggregation move implicit in the Red Lion Court's emphasis on the right of "the public" to receive access to a broad range of ideas and viewpoints. And, of course, group aggregation is conspicuous, in its presence as well as absence, in equal protection law, where the treatment of racial minorities, women, and other groups is most clearly at stake. Unfortunately, courts and theorists seldom attempt to explain when interpersonal offsets are appropriate or why it is that sometimes individuals matter and other times groups matter. The most courts have to offer is the occasional assertion that rights belong to individuals rather than groups. ${ }^{212}$ While some liberal theorists do offer elaborate theories according to which the individual is the locus of moral rights, ${ }^{213}$ their arguments are at too high a level of

problematic despite its consistency with equal treatment across entire individual lives, we might also find problematic the idea that chronologically remote harms and benefits can offset one another. Perhaps constitutional rights protect multiple "selves" within the course of an entire human lifespan, so that benefits to one such self cannot offset harms to another (barring group aggregation of selves back together into a single human life!).

For purposes of this Article, however, we need not pursue these speculations further. Perhaps philosophical arguments along these lines could justify very loose germaneness and nexus constraints that might become relevant at the outer limits of aggregation. But they cannot possibly account for the far more restrictive limitations on aggregation that are applied by courts and commentators to resolve actual constitutional controversies, much less for their highly selective application. In most of the examples discussed in this Part, offsetting benefits and harms come in the same currency, and loose limitations on temporal aggregation would be trivially constraining.

Finally, as a purely descriptive matter, we might look to the behavioral economics and psychology literature on "framing" and "mental accounting" to explain intuitions about which costs and benefits go together and which are unrelated. E.g., Richard H. Thaler, Mental Accounting Matters, in CHOICES, VAlUES, AND FRAMES, supra note 2, at 241. The connection between the use of cognitive frames at the level of individual decisionmaking and framing harms and benefits in law is fascinating but, unfortunately, also beyond the scope of this Article.

212. E.g., Shelley v. Kraemer, 334 U.S. 1, 22 (1948) ("The rights created by the first section of the Fourteenth Amendment are, by its terms, guaranteed to the individual. The rights established are personal rights.").

213. E.g., DwORkin, supra note 69. But see JOSEPH RAZ, ETHICS IN THE PUBLIC DOMAIN 29-44 (1994) (arguing, contra Dworkin, that rights protect collective goods on which individual interests in autonomy and the like depend); Iris Marion Young, Equality of Whom? Social Groups and Judgments of Injustice, 9 J. POL. PHIL. 1 (2001) (arguing that equality should be evaluated at the level of social groups, not individuals). 
abstraction to carry any particular implications for the level at which constitutional harm should be assessed. ${ }^{214}$

In sum, the model of transactional harm offers no guidance as to how to frame constitutional transactions and places no limits on aggregation over time, scope, and group. Because the model relies on such a thin and simplistic understanding of undesirable government behavior-discrete instances of individualized harm-infliction-it simply lacks the conceptual resources to generate a normative theory of how harms and benefits ought to be framed against the background of the continuous relationship between government and citizens. So long as the transactional harm model prevails, we are left with little more than framing by fiat.

\section{TRANSCENDING TRANSACTIONAL HARM}

Up to this point, the Article has been concerned with diagnosing the problem of framing transactions in constitutional law. By now it should be clear that any question of whether government has inflicted harm only becomes meaningful by reference to some transactional frame. And because the appropriate location and expanse of transactional frames is entirely indeterminate within the model of transactional harm, constitutional rules that simply forbid government from inflicting harm or behaving nonneutrally leave courts and theorists virtually unlimited discretion to create or negate government liability by aggregating or disaggregating harms and benefits over time, scope, and group.

Fortunately, this diagnosis also points toward a cure. Transactional framing problems are the inevitable result of applying the common-law model of individualized transactional harm to the continuous, benefit-laden relationship between government and private citizens. Decisions about transactional frames necessarily reflect conscious or unconscious answers to moral, instrumental, and empirical questions about how constitutional cases ought to be decided. Yet these questions cannot be articulated or answered within a model that assumes that every constitutional provision is about preventing a simplistic type of harm to some individual. Consequently, the substantive judgments that determine, or are reflected in, the results of cases are buried in tacit framing decisions beneath an anodyne doctrinal rhetoric of harmlessness and neutrality. By dispensing with the model of transactional harm, we might instead bring these basic questions of goals and mechanisms to the surface by explicitly asking what, exactly, constitutional norms are supposed to accomplish by way of improving the behavior of government and how they might be designed and applied to

214. Pildes, supra note 69 , at $727-33$ (discussing the disconnect between Dworkinian rights theory and how constitutional rights are best conceptualized). 
realize these purposes. Thicker accounts of the goals and mechanisms of constitutional norms may provide the substantive traction necessary to develop sensible approaches to framing.

This Part sketches the form of a solution to the problem of framing transactions in constitutional law. It does so in two steps. The first Section mobilizes a different, but complementary, critique of constitutional law, aimed at the public/private distinction and common-law "baselines." Taken together, the baselines critique and the problem of transactional framing undermine the core corrective justice ideals of harmlessness and neutrality that animate the model of transactional harm. Appreciating that these ideals are vacuous - and the transactional model correspondingly unhelpful as applied to the relationship between government and citizens-should lead us to redirect our attention to alternative models of constitutional norms. As the second Section describes, courts and scholars already have gone some distance toward developing understandings of constitutional provisions that get beyond the naive notion of individualized transactional harm. Once we are clear about the purposes constitutional provisions are meant to serve and the role adjudication might play in furthering those purposes, questions of how to frame transactions become instrumental and potentially tractable at the level of particular constitutional norms.

\section{A. Baselines, Frames, and the Emptiness of Transactional Harm}

The problem of framing transactions connects to a different, but deeply complementary, critique of constitutional law. From the legal realists on, constitutional theorists have repeatedly attacked the state action line and the public/private distinction more generally. These theorists point out that government is actually deeply involved in "private" institutions and ordering, especially common-law rules and market allocations. They demonstrate how perceptions of state action and inaction, neutrality and partiality, depend on preconceptions of a prelegal private sphere that serves as a baseline for evaluating government interventions. Because law plays an inevitable role in structuring the private sphere, these theorists explain, we need not accept its conventional boundaries as a baseline for constitutional analysis of government behavior. There is no reason in theory why the realm of state action could not be extended to the ends of the earth, making government potentially accountable for any social condition thought to offend constitutional values. Certainly government cannot claim neutrality with respect to these conditions if neutrality is taken to mean 
disengagement or lack of causation. Call this line of thought the "baselines" critique of constitutional law. ${ }^{215}$

The problem of transactional framing begins where the baselines critique leaves off. Transactional framing is conceptually independent of, and subsequent to, the baselines problem of how state action is identified. No matter what the boundaries of government's domain of responsibility, inasmuch as constitutional violations are modeled as discrete, harm-causing transactions, the framing question of how many and what types of governmental harms and benefits to include within the transactional frame will arise. The prior question of which harms and benefits count as "governmental" is mostly beside the point. To be sure, the baselines critique helps us to recognize many government benefits hidden within status quo practices and distributions that have come to seem natural and extralegal, and thus multiplies the possibilities for framing. ${ }^{216}$ But really any plausible conception of the public sphere will be sufficiently rich in reciprocal benefits and burdens for the types of framing issues discussed in this Article to arise. Put slightly differently, the baselines critique is largely a jurisdictional matter: It is concerned with defining the domain of government's constitutional accountability. The problem of framing transactions, on the other hand, is concerned with how constitutional law substantively evaluates government's behavior within the jurisdiction of governmental harms and benefits in which constitutional norms apply, irrespective of where or how the boundaries of that jurisdiction are established. Whereas the baselines critique diagnoses the central problem of constitutional law as the absence of any meaningful line between public and private, the difficulty of framing constitutional transactions implicates a different, but perhaps equally fundamental, problem: how to evaluate whether the government has behaved fairly within the domain of its responsibility (however this domain is defined).

The baselines critique and the problem of transactional framing each emphasize an independent sense in which constitutional law appeals to an incoherent ideal of government neutrality in structuring transactions. Constitutional law often defines government "neutrality" as preserving

215. Most of the basic ideas driving the baselines critique were originally developed by Hale. See Robert L. Hale, Bargaining, Duress, and Economic Liberty, 43 ColuM. L. REV. 603 (1943); Robert L. Hale, Coercion and Distribution in a Supposedly Non-Coercive State, 38 POL. SCI. Q. 470 (1923); Hale, supra note 109; see also BARBARA H. FRIED, THE PROGRESSIVE ASSAULT ON LAISSEZ FAIRE: ROBERT HALE AND THE FIRST LAW AND ECONOMICS MOVEMENT (1998) (presenting and illuminating Hale's work). Prominent modem exemplars of the baselines critique include SEIDMAN \& TUSHNET, supra note 106; and SUNSTEIN, supra note 106, at 353.

216. By emphasizing that common-law property entitlements, among other things, are as much the product of government as explicit subsidies, baselines theorists bring these entitlements into the category of government benefits. For instance, the baselines critique reminds us that newspapers are "subsidized" by trespass laws just as broadcasters are subsidized by government licenses. See SUNSTEIN, supra note 175, at 109; supra notes 170-176 and accompanying text. 
some status quo baseline distribution. Government inflicts harm only when it causes deviations from the baseline distribution. The baseline critique argues that neutrality defined in this way is merely a mirage: Because the status quo distribution is itself shaped by government, government cannot claim neutrality when it leaves that distribution intact rather than rearranging it. Government can never be neutral, the argument goes, because it is always already responsible for everything. ${ }^{217}$ Notice, however, that this argument debunks a special kind of "neutrality," one synonymous with disengagement or noninvolvement. Government cannot be neutral in this sense because government is always implicated in any existing distribution of entitlements or set of social arrangements. But constitutional law also, and perhaps more commonly, distinguishes neutral government behavior from harm infliction by appealing to a different, more substantive sense of neutrality. If a harm inflicted by government on an individual citizen is compensated for by an offsetting benefit, then we might say that government has treated the citizen, on balance, neutrally. Here, "neutral" is being used in a substantive, net-outcome sense rather than a procedural, noninvolvement sense.

The problem of transactional framing implicates this second, substantive sense of neutrality. ${ }^{218}$ Constitutional law typically identifies harm-causing transactions not by reference merely to government's reshuffling of some existing distribution, but instead by reference to the net reduction in welfare experienced by some individual or group-that is, substantively nonneutral treatment. Of course, in order to measure a reduction in welfare, one needs to hold constant some baseline distribution. What the baselines critique misses, however, is that measurements of welfare reduction depend not only on the baseline distribution from which changes are measured but also, crucially, on which government harms and benefits are included within the relevant transaction. Constitutional law often reaches into the status quo selectively to pull out government benefits for inclusion within a transaction. How a transaction is framed will determine how much of the status quo is incorporated into the transaction itself and how much is left outside the transaction as a baseline from which 53.

217. See SEIDMAN \& TUSHNET, supra note 106, at 27-28; SUNSTEIN, supra note 106 , at 351-

218. For example, the baselines critique of Lochner-era economic due process focuses on the Supreme Court's treatment of existing distributions of wealth and entitlements as prelegal, so that government acted nonneutrally by interfering with those distributions, whereas maintaining them would have been neutral. The demise of Lochner came when the Court recognized that existing distributions are no less a product of government than redistributions and, therefore, that neutrality in the procedural, noninvolvement sense was impossible. SUNSTEIN, supra note 106, at 40-67. Through the lens of transactional framing, in contrast (but in complement), the issue is substantive neutrality. Even accepting, for the sake of argument, that particular redistributions might be considered substantively nonneutral, this form of neutrality might be restored by aggregating multiple redistributions over time and scope. See supra notes $119-130$ and accompanying text. 
any net change in welfare will be measured. Sometimes, as the baseline critique emphasizes, constitutional law defers to the status quo by framing transactions narrowly. But, just as often, it takes pieces of the status quo into account when evaluating whether government has inflicted a net harm. The problem of transactional framing questions how much and which parts of the status quo should be incorporated into the transactions that are governed by substantive neutrality norms. The baselines critique, in debunking procedural neutrality, shows that there is no reason to privilege zero and none as the answers to those questions. As the transactional framing problem illustrates, however, this still leaves all other possible answers on the table.

Taken together, the baselines and transactional framing critiques teach the important lesson that constitutional liability must be based on something more than a simplistic conception of individualized transactional harm reflecting a downward departure from government neutrality. Both lines of argument follow from the insight that government and citizens are engaged in a multifaceted, long-term relationship, comprising innumerable interactions over an expansive scope of activities. This is what makes disentangling the public from the private, state action from nonstate action, so difficult. This is also what makes it so difficult to decide which of the innumerable harms and benefits passed back and forth between government and citizens should be taken into account in framing transactions for purposes of identifying constitutionally cognizable harms. Analogizing constitutional violations to car crashes or contract breaches for purposes of identifying transactional harm will not do, both because there is no neutral status quo ante in which government and citizens are strangers to one another from which harm can be measured, and because there are no natural boundaries of the transaction that tell which costs and benefits to count in assessing harm.

This analysis leaves us without any meaningful sense of "harm" inflicted on private citizens by government, and - the flip-side of this-also without any meaningful sense of government neutrality. ${ }^{219}$ Conventional understandings of constitutional rights, which make heavy use of such notions, are nothing more than empty, formal vessels. Whatever is wrong with government's taking private property without just compensation, it cannot merely be that government inflicts an economic harm on the property owner or treats her nonneutrally. The problem with instances of race or gender discrimination cannot merely be that government behaves nonneutrally by inflicting individualized, race- or gender-based harms. Government does not offend First Amendment values merely by infringing

219. The same is true with respect to interactions among government units in separation of powers and federalism cases. 
on self-expression or by marginally burdening or benefiting some religious or irreligious organization or practice. In order to give content to these and other constitutional rights, we need something more than vacuous ideals of government neutrality or harmlessness.

The baselines and transactional framing critiques expose other confusions inherent in applying the corrective justice structure of the transactional harm model to constitutional law. The common-law model of transactional harm is based on the principle of distributive neutrality. Liability arises as a result of some discontinuous interaction that disrupts the status quo distribution of wealth, welfare, or entitlements as between two private parties-usually in the form of a nonconsensual redistribution. The remedial goal of the legal regime is either to prevent such redistributions from occurring or, once they do occur, to restore the status quo ante distribution. Protecting exogenous distributions against nonconsensual private redistributions is a central organizing principle of much of private law-whether understood in terms of the moral theory of corrective justice, which sharply distinguishes justice in rectification from justice in distribution, ${ }^{220}$ or economics, which relegates redistribution to presumptively more efficient tax and transfer mechanisms. ${ }^{221}$ Private law's commitment to distributive neutrality thus reflects not an outright opposition to redistribution, but an institutional division of labor: While common-law and some other private-law regimes operate on one track to protect existing distributions against private redistribution, government simultaneously operates on another track to redistribute wealth and entitlements in pursuit of distributive justice, enhanced welfare, or other social goals. ${ }^{222}$ Inasmuch as redistribution in various forms is a crucial part of government's role, it would be nonsensical for legal regimes regulating its conduct to mandate distributive neutrality in the same way common-law regimes mandate distributive neutrality for private actors.

Yet when constitutional rights are conceptualized on the common-law model of transactional harm, this is precisely what they seem to demand. In many areas of constitutional law, government is understood to inflict harm, or to depart impermissibly from neutrality, when it engages in redistribution that leaves some individuals or groups worse off than they were relative to some status quo baseline. When government redistributes wealth from a

220. See Stephen R. Perry, On the Relationship Between Corrective and Distributive Justice, in 4 OXFORD ESSAYS IN JURISPRUDENCE 237 (Jeremy Horder ed., 2000).

221. See Louis Kaplow \& Steven Shavell, Why the Legal System Is Less Efficient than the Income Tax in Redistributing Income, 23 J. LEGAL STUD. 667 (1994). But see Chris William Sanchirico, Taxes Versus Legal Rules as Instruments for Equity: A More Equitable View, $29 \mathrm{~J}$. LEGAL STUD. 797 (2000).

222. See Levinson, supra note 61 , at 411-14; $c f$. JOHN RAWLS, A THEORY OF JUSTICE 87-88 (1971) (making clear that distributive justice principles apply at the level of the basic structure of society, not at the level of individual conduct). 
property owner, for example, it looks like a takings violation; when government redistributes speech opportunities in order to diversify public discourse, it looks like a free speech violation; and the like.

The baselines and transactional framing critiques disparage a blanket constitutional requirement of distributive neutrality in different, but again complementary, ways. The baselines critique largely accepts, as a descriptive matter, that government is prohibited by constitutional law from engaging in redistribution. Thus, as a normative matter, it criticizes the conservative commitment of public-law regimes to preserve status quo distributions that may be unjust or undesirable. The only claim of normative priority that can be generated on behalf of these existing distributions is that government interference would be nonneutral (again, in the procedural, noninvolvement sense); but the baselines critique has already debunked any such claim to neutrality by pointing out that government is always already implicated in any existing distribution. ${ }^{223}$ Viewing constitutional law through the lens of transactional framing, however, reveals a somewhat more complicated accommodation of the apparent distributive neutrality requirement with the fact and necessity of government redistribution. By aggregating over time, scope, or group, constitutional doctrine can virtually always make government redistributions look like corrective-justicecompatible restorations of some status quo. The model of transactional harm does formally prohibit redistribution. But because there are so many harms and benefits from which to choose, what in fact counts as a redistribution, as opposed to a distributively neutral package of offsetting harms and benefits, is, at least in theory, entirely up for grabs.

For example, liberal critics excoriate modern equal protection doctrine for its focus on transactional harm to individuals at the expense of ignoring - or, when it comes to constitutional prohibitions on affirmative action, actually exacerbating - the subordinate status of blacks as a social group. ${ }^{224}$ Baselines theorists amplify this criticism by pointing to all the ways government is responsible for existing inequalities between blacks and whites and ridiculing the idea that equal protection doctrine creates racial neutrality by forbidding race-based assignment of burdens and benefits. ${ }^{225}$ It is important to recognize, however, that equal protection's rhetorical commitment to preventing transactional harm to individuals is not, in practice, irreconcilable with the project of ameliorating broad-scale racial inequality. Just focusing on affirmative action, it is always possible to manipulate transactional frames in order to redescribe race-based benefits as compensatory, at the individual or group level, for race-based harm. No

223. See Sunstein, supra note 15.

224. See Owen M. Fiss, Groups and the Equal Protection Clause, 5 PHIL. \& PUB. AFF, 107 (1976).

225. SEIDMAN \& TUSHNET, supra note 106, at 91-116. 
matter how much race-based redistribution government chooses to engage in, the appearance of neutrality-here, in the substantive, net-outcome sense-can always be restored by pulling more offsetting harms into the same transactional frame or switching from individual- to group-level analysis. Even on the transactional harm model, constitutional law can allow government considerable latitude to engage in redistribution relative to some proximate status quo baseline. The requisite distributive neutrality is maintained by reframing the transaction as one that is substantively neutral-not redistributive after all-relative to some strategically reestablished, more remote baseline.

Takings law provides an even clearer example of this pattern of rhetorical tension and doctrinal accommodation when it comes to redistribution. The conventional understanding of the takings right is that it protects individuals from bearing severely disproportionate economic burdens that should instead be spread over taxpayers generally. ${ }^{226}$ Yet it has long been accepted that government has an important role to play in regulating the economy and purposefully redistributing wealth through progressive taxation and social welfare programs. Again, tension arises between the prohibition on transactional harm and broader distributional goals. Takings doctrine resolves this tension in the first instance by distinguishing physical dispossessions of property, which usually trigger just compensation, from regulation and taxation, which usually do not. This distinction seems most precarious in those regulatory takings cases where the types of economic burdens imposed on individual property seem quite indistinguishable from straightforward dispossessions of property. As we have seen in these cases, takings law often negotiates this tension by manipulating transactional frames to convert seemingly redistributive regulations into distributively neutral ones. ${ }^{227}$ Government regulation, say a zoning ordinance, has inflicted a severe economic loss on an individual that is, functionally and economically, indistinguishable from the physical dispossessions that routinely require just compensation. Nevertheless, the

226. See supra note 7 and accompanying text.

227. Baselines theorists portray courts as hamstrung in takings cases by their inability to understand that status quo property holdings are themselves the products of government and, for that reason, ought not to be privileged over any redistribution government might now choose. And when courts occasionally do allow government to redistribute propenty entitlements without compensation, baselines theorists celebrate the general repudiation of constitutional law's commitment to distributive neutrality-perhaps without fully appreciating that redistribution can always be reconciled with distributive neutrality by adjusting transactional frames. For example, Seidman and Tushnet laud Miller v. Schoene, 276 U.S. 272 (1928), which rejects a takings challenge to a state law permitting the destruction of cedar trees in order to prevent disease from spreading to apple trees, for undermining "the conceptual structure that had made sense of constitutional law." SEIDMAN \& TUSHNET, supra note 106, at 27. But it would have been easy enough for the Court in Miller simply to point to offsetting benefits to the owners of cedar trees, or to aggregate cedar tree and apple tree owners in a group, and thereby restore the appearance of distributive neutrality. 
court explains, compensation to the individual is unnecessary because she is implicitly compensated by the benefits of the zoning scheme as it is applied to neighboring parcels. Or, the zoning scheme, while perhaps economically disadvantageous to the individual, carries offsetting benefits to other individuals in the neighborhood and therefore maintains group-level distributive neutrality.

From the perspective of transactional framing, then, the primary problem with applying the transactional harm model is not that, because it misses the point of the private/public division of redistributive labor, it ends up absolutely prohibiting government redistribution. The transactional model does miss this point, but aggregation and reframing techniques nevertheless allow courts and theorists to reconcile redistribution, where they are so inclined, with prohibitions on transactional harm. Instead, the primary problem is that the model provides no answers to the crucial questions of how much or which kinds of redistributions are permitted with respect to various constitutional rights. Indeed, it prevents these questions from even being asked. By representing every permissible redistribution as a net-outcome-neutral transaction while striking down every impermissible one as nonneutral or harm-inflicting, constitutional law need only commit to empty, and therefore noncontroversial, norms of neutrality and harmlessness. The difficult and potentially controversial judgments that actually decide the cases-the ones about which redistributions, exactly, are permissible and which are impermissible-are never articulated or defended but simply buried underneath implicit framing choices.

\section{B. Framing Substantive Constitutional Norms}

Transactional framing seems arbitrary when constitutional rights are defined as empty individual entitlements not to be harmed or treated nonneutrally by government with respect to particular interests. But constitutional rights need not be modeled in the same way as common-law ones. Across many areas of constitutional law, courts and theorists have explored ways of thinking about constitutional norms that contemplate normative goals more substantive than simple-minded nonneutrality, as well as the instrumental mechanisms for achieving these goals within the institutional limitations of judicial review. ${ }^{228}$ These approaches, while pursuing very different normative visions, commonly tend to redirect the focus of constitutional adjudication from identifying and remedying harm to individuals to addressing broader social problems related to political

228. This Article takes an entirely agnostic stance toward the sources of constitutional norms in general, and here in particular. They may be derived from the text of the Constitution, history, moral philosophy, pragmatic policy analysis, or any other authoritative source. 
process, distributive outcomes, or the structure of institutions. ${ }^{229}$ Perhaps because the conventional common-law model continues to exert so much influence, much of this thinking is fragmentary and underdeveloped. Some of it seems plainly misguided. Nevertheless, for purposes of pointing the way beyond the problem of framing transactions in constitutional law, it may be enough just to recognize that constitutional norms need not be oriented around transactional harm to individuals and to envisage how various substantive orientations might structure the framing enterprise.

Suppose, for example, that instead of protecting individuals against concentrated economic burdens, the constitutional prohibition on uncompensated takings is understood to serve some other more systemic or structural purpose. The scholarly literature suggests that such purposes might include creating incentives for government to make efficient, costbenefit-justified regulatory decisions, ${ }^{230}$ discouraging interest-group rentseeking by limiting government's power to redistribute wealth; ${ }^{231}$ and bolstering social stability and individual security by preventing government from continuously readjusting property entitlements. ${ }^{232}$ Because individualized economic harm is not central to any of these understandings, transactional frames will not conclusively determine the existence of a constitutional violation by creating or negating net economic harm. To be sure, we still need some way of framing takings transactions for purposes of constitutional adjudication-some way of deciding which economic dislocations will be bundled together and defined as an uncompensated taking. But now, perhaps, the size and position of the relevant frame can be determined instrumentally, in light of whatever type of bad government behavior the Takings Clause is designed to prevent.

Assume, for example, that the point of takings law is to reduce the opportunities for socially wasteful interest-group rent-seeking by restricting the set of entitlements that government is permitted to redistribute. ${ }^{233} \mathrm{On}$ this understanding, questions of whether to include offsetting benefits in the

229. More robust understandings of constitutional norms need not be "systemic" in this sense. Perhaps some constitutional norms really do directly serve the purpose of protecting individuals against specific types of harm. The special challenge confronting individual harmbased accounts, though, is to explain why offsetting benefits are irrelevant or to specify which kinds are relevant in what circumstances.

230. See, e.g., EPSTEIN, supra note 116, at 182-83; POSNER, supra note 35, at 64; Lawrence Blume \& Daniel Rubinfeld, Compensation for Takings: An Economic Analysis, 72 CAL. L. REV. 569, 571 (1984); Thomas J. Miceli \& Kathleen Segerson, Regulatory Takings: When Should Compensation Be Paid?, 23 J. LEGAL STUD. 749, 758-59 (1994). But see Levinson, supra note 61, at 354-61 (stressing that government internalizes only political costs, not financial ones).

231. See EPSTEIN, supra note 94 , at 281.

232. See CASS R. SunSTEIN, Free MaRKETS AND SOCIAL Justice 207-11 (1997); Robert E. Goodin, Compensation and Redistribution, in NOMOS XXXIII: COMPENSATORY JUSTICE, supra note 15 , at 143 .

233. See EPSTEIN, supra note 94. Of course there are many difficulties with this way of thinking about takings that are unrelated to transactional framing. 
transactional frame can be answered in light of the normative goal of discouraging redistributive wrangling by interest groups. If courts generally permitted government to introduce benefits to offset the economic losses occasioned by redistributions within the off-limits set of entitlements, this would defeat the hypothesized purpose of the takings norm-all entitlements would be fair game for redistribution, and interest groups would furiously compete with one another to get the greatest possible share of benefits and the least possible share of burdens. Far from offsetting harm, the availability to interest groups of benefits would simply exacerbate the problem that the Takings Clause is, on this understanding, supposed to solve. Consequently, the best framing strategy for minimizing redistributive rent-seeking might be to slice transactions narrowly, prohibiting each isolated instance of redistribution.

Notice that reorienting the takings norm away from individualized transactional harm and toward systemic problems with the behavior of government both lowers the stakes of framing and provides some reasons for choosing one frame over another. The placement of frames no longer dispositively determines constitutional liability by creating or negating individualized harm, but instead simply directs judicial attention to the types and patterns of government behavior that are significant in light of the goals and mechanisms of the particular constitutional norm. The choice of frames no longer seems mysteriously independent of courts' and theorists' understanding of the purposes of the underlying norm, but instead follows instrumentally from that purpose. As the brief survey that follows suggests, this basic approach to framing constitutional transactions is generalizable to other constitutional provisions once they are reconceptualized as serving purposes other than protecting individuals from transactional harm.

Unconstitutional conditions doctrine has been explained by theorists not just in terms of protecting individuals against burdens on the exercise of their constitutional rights, but also in more systemic terms, as a means of preventing the externalities that arise when individuals trade for private gain constitutional entitlements that carry broader social benefits, ${ }^{234}$ deterring rent-seeking and encouraging public-regarding politics, ${ }^{235}$ or maximizing the social surplus by prohibiting some forms of redistribution. ${ }^{236}$ Similarly, theorists who advocate a more restrictive form of rationality review are concerned not with the harm suffered by individuals or groups who come out on the losing end of statutes and regulations, but with the political process goal of encouraging legislatures to deliberate about the public good rather than merely acting on "naked

234. See SUNSTEIN, supra note 106, at 303-04; Merrill, supra note 106, at 1153-57.

235. See Sullivan, supra note 109 , at 1456-76.

236. See EPSTEIN, supra note 116. 
preferences" in favor of politically influential interest groups. ${ }^{237}$ By abandoning individualized transactional harm as the normative touchstone, these systemic accounts provide substantive guidance about how transactions should be framed. If the point of unconstitutional conditions doctrine and rationality review is to encourage legislatures to engage in republican, public-regarding deliberation, for instance, then constitutional values are offended the moment harms and benefits are assigned through a legislative process corrupted by interest-group influence. Inasmuch as the concern is the qualitative nature of the political process, whether the resulting harms and benefits cancel one another out at some level of aggregation is irrelevant. From a republican or deliberative-democracy perspective, the last thing we should care about in enforcing these constitutional doctrines is what numbers are posted up on the interest-group scoreboard. The question of how to frame transactions, therefore, is both deflated in importance and amenable to instrumental solutions. If offsetting benefits are irrelevant, and the only goal is to encourage deliberative politics, then perhaps courts should evaluate reasonably small slices of government activity in order to extirpate interest-group-corrupted political programs as they arise.

At least two broad strands of race and gender equal protection jurisprudence are concerned with goals other than preventing transactional harm to individuals or groups. The first, which significantly shapes modern doctrine, is the norm of color- or gender-blindness, which flatly prohibits government from taking race or gender into account in distributing benefits or burdens. A categorical ban on racial classifications might be justified by concerns about expressive effects and social meaning. Racial classifications, the argument goes, reinforce the cultural salience of race and beliefs about racial differences ${ }^{238}$ and encourage politics along racial lines, ${ }^{239}$ thereby contributing to race discrimination and racial divisiveness in society. Likewise, gender classifications might be thought to reinforce undesirable gender stereotypes to the detriment of both men and women. ${ }^{240}$

237. See Cass R. Sunstein, Interest Groups in American Public Law, 38 STAN. L. REv. 29 (1985); Sunstein, supra note 122.

238. Adarand Constructors, Inc. v. Pena, 515 U.S. 200, 241 (1995) (Thomas, J., concurring in part) ("So-called 'benign' discrimination teaches many that because of chronic and apparently immutable handicaps, minorities cannot compete with them without their patronizing induigence. Inevitably, such programs engender attitudes of superiority or ... stamp minorities with a badge of inferiority and may cause them to develop dependencies ...."); Regents of the Univ. of Cal. v. Bakke, 438 U.S. 265, 298 (1978) (opinion of Powell, J.) (asserting that racial preferences "may only reinforce common sterentypes holding that certain groups are unable to achieve success without special protection based on a factor having no relation to individual worth").

239. City of Richmond v. J.A. Croson Co., 488 U.S. 469, 510-11 (1989).

240. See, e.g., Orr v. Orr, 440 U.S. 268, 283 (1979) ("Legislative classifications ... on the basis of gender carry the inherent risk of reinforcing stereotypes about the 'proper place' of women and their need for special protection."); see also ANDREW KOPPELMAN, 
In this view, the point of equal protection is not to protect any individual against race- or gender-based harm. (Of course, the longer-term goal of reducing the social significance of race and gender may ultimately prevent numerous and various harms to individuals. But that kind of nontransactional harm prevention is a byproduct of the equal protection norm rather than its immediate point; it does not affect how the doctrine operates on a case-by-case basis.) From this perspective, every race or gender classification inflicts the relevant type of social harm, and there is no sense in which government can engage in activity of the opposite valence to create offsetting benefits. Given that framing transactions will no longer affect whether the relevant constitutional harm exists (because there is no question of offsetting it), there is no reason to expand transactional frames beyond a very narrow examination of each instance of government race- or gender-consciousness. Perhaps government should be held liable every time it takes race or gender into account when allocating benefits and burdens.

The second strand in equal protection advocates a different social goal: not eliminating race- or gender-consciousness but alleviating the systematic subjugation of racial minority groups and women. ${ }^{241}$ In this view, equal protection law should forbid government action that perpetuates the subordination of blacks or women but should permit, or perhaps even require, government to take steps to undermine social structures that contribute to the subordinate status of these groups. We have seen that even where courts have been sympathetic to antisubjugation approaches to racial equality, they have stayed within the framework of transactional harm and simply broadened transactional frames-for example, to allow more "remedial" affirmative action benefits to be offset against the harm of past race discrimination. Full-fledged acceptance of antisubjugation as the goal of equal protection, however, would obviate the need to offset harms and benefits by manipulating frames. Affirmative action programs could be justified in straightforward redistributive terms (or in terms of the forwardlooking benefits of racial or gender diversity). Framing issues would not disappear entirely, of course, since courts would still have to decide whether to enforce, say, a narrowly framed prohibition on any government program that further disadvantaged a subordinated group, or a more broadly

ANTIDISCRIMINATION LAW AND SOCIAL EQUALITY 131-36 (1996) (elaborating and critiquing theories of sex discrimination based on "stereotyping").

241. On race, see, for instance, Fiss, supra note 224 , which advocates an interpretation of equal protection that would "give expression to an ethical view against caste, one that would make it undesirable for any social group to occupy a position of subordination for any extended period of time." Id. at 150-51. On gender, see, for instance, CATHARINE A. MACKINNON, TOWARD A FEMINIST THEORY OF THE STATE (1989); and Mary E. Becker, Obscuring the Struggle: Sex Discrimination, Social Security, and Stone, Seidman, Sunstein \& Tushnet's Constitutional Law, 89 COLUM. L. REv. 264 (1989). 
framed requirement that a wide swath of government programs over a period of some years work to the benefit (or at least not to the detriment) of such groups. Or, perhaps the best institutional accommodation of the constitutional norm would be for courts to turn over primary responsibility for racial equality to the political branches, only intervening if they perceived some broadly framed, systematic exacerbation of inequality or lack of progress toward achieving equality. This is not a simple or obvious decision, but at least it is one that can be grappled with instrumentally, in light of the anticipated pattern of government activity and the institutional capabilities of courts. The important point is that questions about how best to realize an antisubjugation norm in a particular institutional context are amenable to analysis in a way that normatively rudderless attempts to frame transactions for purposes of assessing neutrality or individualized harm are not.

Free speech doctrine is predominantly concerned with the transactional harm of governmental restriction of individual speech, which invites all the usual framing questions about how to count offsetting subsidies when seeking to identify a net suppression of speech. As an alternative, consider the systemic, civic republican understanding of the free speech norm that competes for attention in First Amendment doctrine and theory. ${ }^{242}$ Republican theorists insist that the primary free speech concern should not be protecting individual autonomy and self-expression but rather collective, democratic self-governance. If speech law is supposed to serve the broad social value of fostering diverse and robust public debate, then, at the very least, courts should recognize that discrete abridgements of speech by government do not by themselves implicate the concerns animating the constitutional norm. Now, it does not necessarily follow that transactions ought to be broadly framed. Courts might sensibly decide to prohibit discrete abridgements on a case-by-case basis, not because they are ultimately concerned about individual harm, but for prophylactic reasons: If courts cannot reliably verify that governmental interferences with expression are integral to a broader effort to bolster deliberative democracy, perhaps the risks that government will suppress speech for malign reasons outweigh any potential benefits of allowing greater flexibility. Whatever the optimal institutional accommodation of a systemic free speech norm might turn out to be, the important point, again, is that we can address the issue in terms of goals and mechanisms. Constitutional analysis can move beyond hopeless questions about whether government has interfered with an individual's expression or instead, on net, subsidized it.

Along the same lines, the Religion Clauses need not be understood transactionally, as prohibiting discrete government acts that are nonneutral

242. See supra notes $177-178$ and accompanying text. 
among religious groups or between religion and nonreligion. One systemic understanding of free exercise and establishment emphasizes government's obligation to foster religious pluralism. ${ }^{243}$ Instead of viewing religious accommodations discretely, as special, nonneutral benefits to religion, the pluralist perspective would ask whether the practice of making such accommodations contributes to religious diversity over society as a whole. Here again, we still need to decide whether to ask this question of smaller or larger slices of government activity. Is government required to enhance religious pluralism at the level of every statute or only over some broader set of legislative outputs? But, again, this type of framing question can be answered by reference to institutional design; it does not demand the normatively dispositive assessment of offsetting benefits required in framing transactional harm. Other systemic understandings of Religion Clause jurisprudence emphasize strict separation between government and religion, on the theory that government entanglement with religion will both threaten religious liberty and create public dissension and strife as religious groups compete for political favors. ${ }^{244}$ These understandings would seem to answer transactional framing questions more clearly and categorically. If any government involvement with religion is constitutionally problematic per se, and if government benefits to religion do not offset the constitutional harm but rather exacerbate it, then transactions should be framed as narrowly as possible.

More work clearly needs to be done to develop these ideas, but for now it is enough to see that questions of how to frame constitutional transactions are not hopelessly indeterminate. They seem so only when we insist on superimposing the common-law model of disjointed transactional harm on the continuous relationship between government and citizens. When constitutional norms are conceived and institutionalized in more robust, systemic ways, the problem of transactional framing is transformed from one of conceptual incoherence to one of instrumental institutional design. Needless to say, all of these substantive conceptions will be controversialindeed, they will be controversial precisely because they have substance. But this is where the attention of constitutional analysis ought to be focused: on the goals and mechanisms of constitutional norms. Instead, the basic moral, instrumental, and institutional questions that structure constitutional law and theory are too often masked and muddled by the facile equation of constitutional rights with common-law ones.

243. See Lemon v. Kurtzman, 403 U.S. 602, 622-23 (1971) (discussing the dual-edged danger of church-state entanglement, with reference to "political division along religious lines" and the need to "protect religious worship from the pervasive power of government"); TRIBE, supra note 7 , at $1275-84$.

244. See Michael W. McConnell, The Origins and Historical Understanding of Free Exercise of Religion, 103 HARV. L. REV. 1409 (1990). 
Appreciating the difficulties of applying the common-law model of transactional harm to the relationship between government and citizens is a necessary first step toward the development of alternative models that better reflect the purposes and capabilities of constitutional law and, not coincidentally, solve the problem of transactional framing. 